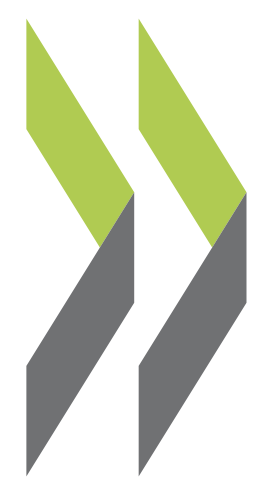

OECD Economics Department Working Papers No. 736

Promoting Competition to Strengthen Economic Tomasz Koźluk Growth in Belgium 


\section{Unclassified}

ECO/WKP(2009)77

Organisation de Coopération et de Développement Économiques

Organisation for Economic Co-operation and Development

03-Dec-2009

ECONOMICS DEPARTMENT

English, French

PROMOTING COMPETITION TO STRENGTHEN ECONOMIC GROWTH IN BELGIUM

ECONOMICS DEPARTMENT WORKING PAPER No 736

By Tomasz Koźluk

All OECD Economics Department Working Papers are available on the OECD Intranet website at www.oecd.org/eco/Workingpapers

JT03275689

Document complet disponible sur OLIS dans son format d'origine

Complete document available on OLIS in its original format 


\section{ABSTRACT/RESUMÉ}

\section{Promoting competition to strengthen economic growth in Belgium}

Prices for many goods and services in Belgium are higher than in other countries, reflecting generally weak competitive pressures. The government has recently introduced several reforms to strengthen the competition policy framework. Nevertheless, to reap the full benefits of competitive markets, past reforms should be complemented with a number of further measures. The powers of the Competition Authority can still be enhanced. Its effective degree of independence, substantially improved in the recent reform, and its accountability should be monitored in order to assess whether further measures in this direction are needed. In the retail sector competition-restricting regulations still protect existing companies against new entry and inhibit the diffusion of new business models and technologies. The reform efforts in the network sectors remain patchy. In the energy and telecommunication sectors the main issues are the dominant positions of the incumbents and the failure of network sector regulators to introduce a level playing field in order to allow new entry and expansion of competitors. In other sectors, such as postal services and rail transport, major steps towards liberalisation are still to come. Overall, sectoral regulators will need more independence and powers in order to tackle uncompetitive behaviour of the incumbents, while better communication between the regulatory authorities is necessary. These steps should help to secure the necessary basis for bringing productivity growth in line with best performance.

This Working Paper relates to the 2009 OECD Economic Survey of Belgium (www.oecd.org/eco/surveys/belgium).

JEL classification: L41; L43; L50; K23.

Keywords: Belgium; competition; competition policy; retail distribution; network industries; sectoral regulators, economic growth.

\section{$+++$}

\section{Promouvoir la concurrence afin d'affermir la croissance économique en Belgique}

Les prix d'un grand nombre de biens et de services en Belgique sont plus élevés que dans d'autres pays, signe de la faiblesse générale des pressions exercées par la concurrence. Le gouvernement a récemment introduit plusieurs réformes destinées à renforcer le cadre de la politique de concurrence. Néanmoins, pour tirer tout le profit de marchés concurrentiels, les réformes mises en œuvre devraient être complétées par un certain nombre de mesures additionnelles. Les pouvoirs de l'Autorité de concurrence peuvent être encore renforcés. Son degré effectif d'indépendance (sensiblement rehaussé par la récente réforme) et son obligation de rendre compte devraient faire l'objet d'un suivi de manière à évaluer si de nouvelles mesures s'imposent à cet égard. Dans le commerce de détail, les réglementations restreignant la concurrence protègent toujours les entreprises en place contre l'arrivée de nouveaux concurrents et freinent la diffusion de nouveaux modèles économiques et de nouvelles technologies. Les efforts de réforme dans les industries de réseau demeurent parcellaires. Dans les secteurs de l'énergie et des télécommunications, les problèmes tiennent surtout aux positions dominantes des opérateurs historiques et à l'incapacité des autorités de régulation des industries de réseau à instaurer des conditions égales pour tous de manière à permettre l'arrivée de nouveaux concurrents et le développement de la concurrence. Dans d'autres secteurs, comme les services postaux et le transport ferroviaire, d'importantes mesures de libération sont toujours en attente. Globalement, les régulateurs sectoriels ont besoin de plus d'indépendance et de plus de pouvoirs pour contrer le comportement anticoncurrentiel des opérateurs historiques, et il est nécessaire d'améliorer la communication entre les autorités de régulation. Ces mesures devraient contribuer à assurer la base nécessaire pour porter la croissance de la productivité au meilleur niveau.

Ce document de travail se rapporte à l'Étude économique de l'OCDE de la Belgique, 2009 (www.oecd.org/eco/etudes/belgique).

Codes JEL : L41; L43; L50; K23.

Mots Clés : Belgique, concurrence; politique de concurrence, commerce de détail, industries de réseau, régulateurs sectoriels, croissance économique.

Copyright OECD, 2008

Application for permission to reproduce or translate all, or part of, this material should be made to: Head of Publications Service, OECD, 2 rue André Pascal, 75775 Paris Cedex 16, France. 


\section{Table of contents}

Promoting competition to strengthen economic growth in Belgium ......................................................

More competition to benefit productivity, employment and consumer welfare ..........................................5

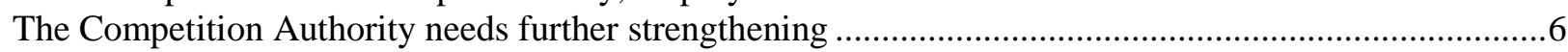

Competition in retail distribution is burdened by heavy regulation....................................................10

Regulators in network industries are faced with dominant positions of incumbents .................................15

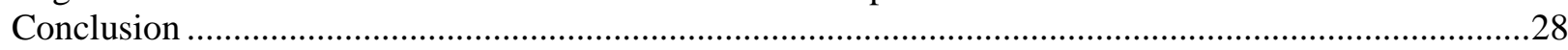

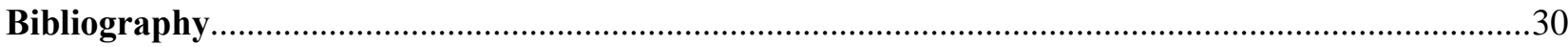

\section{Boxes}

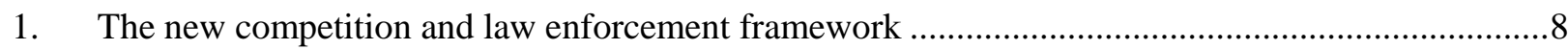

2. Anti-competitive regulation and labour productivity - OECD simulations ...................................12

3. Examples of competition restricting regulation in retail distribution .........................................14

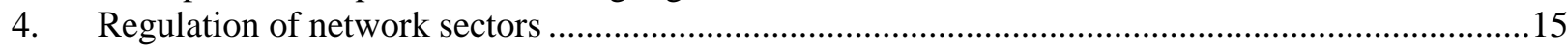

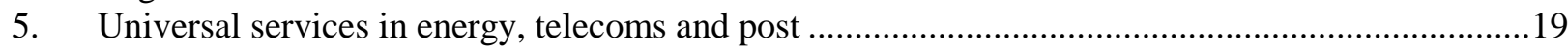

6. The Gaz de France - Suez merger and concentration on the Belgian energy market .....................21

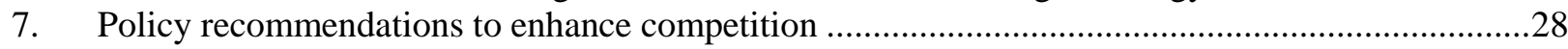

\section{Tables}

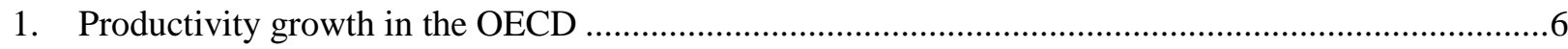

2. The simulated effect of liberalisation on labour productivity in the future .....................................12

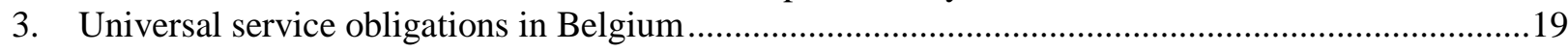

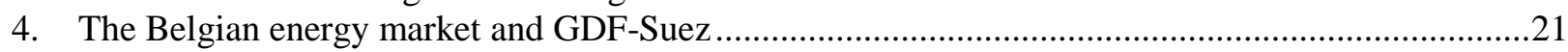

5. Triple-play is significantly more expensive than in France...........................................................23

\section{Figures}

1. Product market regulation in Belgium and the OECD …...........................................................

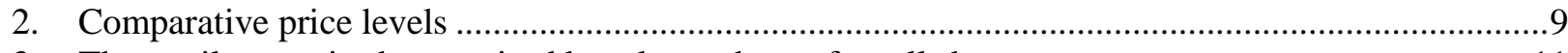

3. The retail sector is characterised by a large share of small shops …..............................................11

4. Belgian retail is characterised by low employment, low productivity growth and strong regulation 13

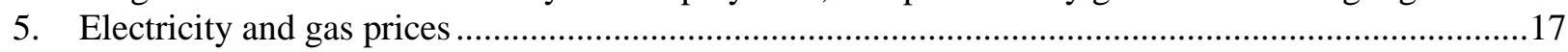

6. Competition restricting regulation in energy and telecommunications ..........................................20

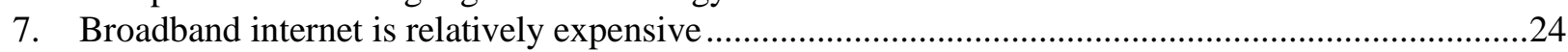

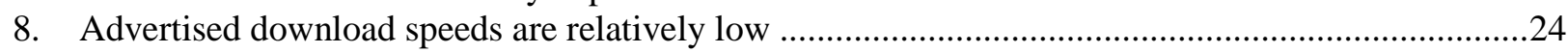

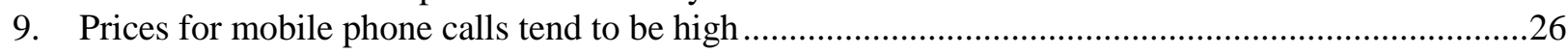


ECO/WKP(2009)77 
ECO/WKP(2009)77

\title{
PROMOTING COMPETITION TO STRENGTHEN ECONOMIC GROWTH IN BELGIUM
}

\author{
by Tomasz Koźluk ${ }^{1}$
}

1. The Belgian government is putting a greater emphasis on competition as a productivity enhancing tool and has implemented a number of reforms in this area. The government is now promoting competition with the objective of increasing consumer welfare, preserving purchasing power and encouraging entrepreneurship through facilitating new entry (Stratégie de Lisbonne, 2008, Accord du Gouvernement, Plan de Relance). However, there remains substantial scope to increase competitive pressures in order to boost potential growth of the economy and benefit consumers. The authorities have identified retail trade, food, energy and telecommunication as priority sectors in this respect. The retail sector regulation is more pervasive than in most OECD countries, protecting existing shops from competitive pressures as the entry of innovative business models and the diffusion of new technologies are inhibited. At the same time, the liberalisation of network sectors has been slower than elsewhere in the OECD while concentration is high and the effective functioning of regulators has proven difficult to achieve. As a result, prices are often higher than in other countries pointing to the need for reducing the barriers to entry and assuring a more level playing field. The paper starts with a general review of the competition framework. Then, the inherently competitive retail trade sector is analysed. Subsequently, the difficulties of introducing competition in the incumbent-dominated network sectors are considered. The paper concludes with a set of policy recommendations.

\section{More competition to benefit productivity, employment and consumer welfare}

2. Over the past ten years, productivity and employment growth have remained somewhat slower relative to many other OECD countries (Table 1). At the same time progress in opening markets to competition has not been as fast as in the leading countries and the amount of restrictions to competition remains above the OECD best practice (Figure 1, Panel A and Wölfl et al., 2009). A growing body of empirical literature points to the existence of a positive link between competition and productivity growth on the one hand (Nicoletti and Scarpetta, 2003, Conway et al., 2006) and between competition and employment on the other hand (Bassanini and Duval, 2006), suggesting that insufficient competition policy enforcement may have lowered economic growth in Belgium. Furthermore, it appears that the Belgian consumer may be paying a high price for the lack of well-functioning, competitive markets (Figure 2). ${ }^{2}$ The final prices of many retail goods appear somewhat higher than the euro area average while prices in network sectors also tend to be on the high side, motivating the review of competition-inhibiting regulation in Belgium.

1. Tomasz Koźluk is an Economist on the Belgium Netherlands desk in the OECD. The paper first appeared as a chapter for the OECD Economics Survey of Belgium, published in July 2009 under the responsibility of the Economic and Development Review Committee. The author is grateful to Jens Høj for his support and guidance for this work. He would also like to thank OECD colleagues Andrew Dean and Robert Ford, Pierre Beynet, Mike Wise and Taylor Reynolds, and Maria Sicilia from the IEA, among others, for useful comments, as well as Sylvie Foucher-Hantala for statistical assistance and Veronique Henriksson and Sylvie Ricordeau for secretarial assistance.

2. The figures presented do not take account of differences in VAT tax rates across countries. However, although the Belgian standard VAT rate is higher than in many euro area countries, the differences are of a small order of magnitude (on average 1.6 percentage point higher) and would not change the conclusion. Furthermore the Belgian VAT tax is characterised by a large number of reductions and exemptions (OECD, 2009). 
Table 1. Productivity growth in the OECD

\begin{tabular}{|c|c|c|c|c|c|c|c|c|c|c|c|}
\hline & Belgium & Germany & Netherlands & France & Italy & Spain & Sweden & Finland & $\begin{array}{l}\text { United } \\
\text { States }\end{array}$ & $\begin{array}{l}\text { Czech } \\
\text { Republic }\end{array}$ & $\mathrm{OECD}^{4}$ \\
\hline \multicolumn{12}{|l|}{$\begin{array}{l}\text { A. Growth decomposition, } \\
1996-2006\end{array}$} \\
\hline $\begin{array}{l}\text { Average GDP growth } \\
\text { Of which: }\end{array}$ & 2.2 & 1.5 & 2.7 & 2.2 & 1.4 & 3.7 & 3.1 & 3.7 & 3.1 & 3.0 & 3.3 \\
\hline Productivity & 1.3 & 1.1 & 1.3 & 1.4 & 0.2 & -0.4 & 2.3 & 2.1 & 1.8 & 3.2 & 1.9 \\
\hline Employment & 1.0 & 0.4 & 1.4 & 0.8 & 1.2 & 4.2 & 0.8 & 1.5 & 1.3 & -0.2 & 1.4 \\
\hline \multicolumn{12}{|l|}{ Of which: } \\
\hline Unemployment ${ }^{1}$ & 0.1 & -0.2 & 0.3 & 0.1 & 0.5 & 1.1 & 0.4 & 0.9 & 0.1 & -0.3 & 0.4 \\
\hline Labour force & 0.8 & 0.5 & 1.1 & 0.7 & 0.8 & 3.0 & 0.4 & 0.6 & 1.2 & 0.1 & 1.2 \\
\hline \multicolumn{12}{|l|}{$\begin{array}{l}\text { B. Labour productivity } \\
\text { growth, } 1996-2006^{2}\end{array}$} \\
\hline Agriculture and forestry ${ }^{3}$ & 1.4 & 2.1 & 2.0 & 1.9 & 2.3 & 0.3 & 5.1 & 3.1 & 5.3 & 6.1 & 2.5 \\
\hline Total manufacturing & 3.1 & 3.8 & 3.0 & 3.6 & 0.3 & 0.7 & 7.2 & 6.6 & 5.1 & 6.4 & 4.1 \\
\hline $\begin{array}{l}\text { Chemicals and } \\
\text { chemical products } \\
\text { Motor vehicles, trailers and }\end{array}$ & 3.0 & 5.5 & 5.6 & 5.9 & 0.4 & -0.7 & 7.9 & 2.5 & 2.9 & 3.2 & 2.9 \\
\hline semi-trailers & 3.8 & 3.0 & $\cdots$ & 3.3 & 0.8 & & 8.9 & 4.8 & & 9.8 & 2.6 \\
\hline Electricity, gas and water & 2.6 & 3.3 & 3.2 & 2.9 & 3.5 & 2.5 & 0.4 & 4.3 & 2.7 & 1.0 & 2.8 \\
\hline Construction & 2.2 & 0.3 & -0.2 & -0.3 & -0.6 & -0.5 & -0.6 & -1.3 & -2.5 & -1.9 & -0.1 \\
\hline Total services & 0.8 & 0.3 & 1.2 & 0.8 & -0.1 & -0.4 & 1.4 & 0.6 & 1.8 & 2.1 & 1.1 \\
\hline Wholesale and retail trade & 0.2 & 1.3 & 2.7 & 0.6 & -0.6 & -1.1 & 3.7 & 2.8 & 3.1 & 5.6 & 3.1 \\
\hline Communication & 2.1 & 3.1 & 4.7 & 4.5 & 2.6 & 0.4 & 3.3 & 4.2 & 4.2 & 2.8 & 3.2 \\
\hline Financial services & 5.3 & 0.3 & 1.6 & 2.3 & 1.9 & 5.8 & 3.4 & 0.5 & 4.0 & 2.7 & 3.6 \\
\hline
\end{tabular}

1. A positive sign indicates that unemployment has declined and contributed to boost output growth.

1996-2005 for Sweden.

Including hunting and fishing

4. Simple average of countries with available data (of AUS, AUT, BEL, CAN, CZE, DNK, FIN, FRA, GER, ESP, SWE, NOR, USA, NLD, HUN, KOR, LUX, ITA, ISL, IRL, PRT). Source: OECD, STAN Edition 2008, database. 


\section{The Competition Authority needs further strengthening}

3. The competition policy framework has notably improved over the past several years as legislation was adapted to EU standards (Box 1). The merger review threshold was raised, freeing up resources to deal with the cases of price fixing and abuse of dominant position. The reform also included changes in the institutional structure of the competition bodies. The Competition Authority is a so-called dual authority, consisting of the Directorate General of the Ministry of Economy (the investigative body) and the Competition Council (the administrative tribunal). The latter includes the Council (a court) and the College of Competition Prosecutors (the investigative and prosecuting body). Further reforms included putting in place a leniency programme and putting an end to the immunity from fines granted to associations of undertakings and professionals under the previous law. The reforms have started to yield visible results: cartel infringements have been found, the leniency programme has begun to work and cartel participants have been fined. Nevertheless, as the improvements to the framework are rather recent, it will take some time for the full effect on competition to be felt, however there still seems room for refining of the setup.

Figure 1. Product market regulation in Belgium and the OECD ${ }^{1}$
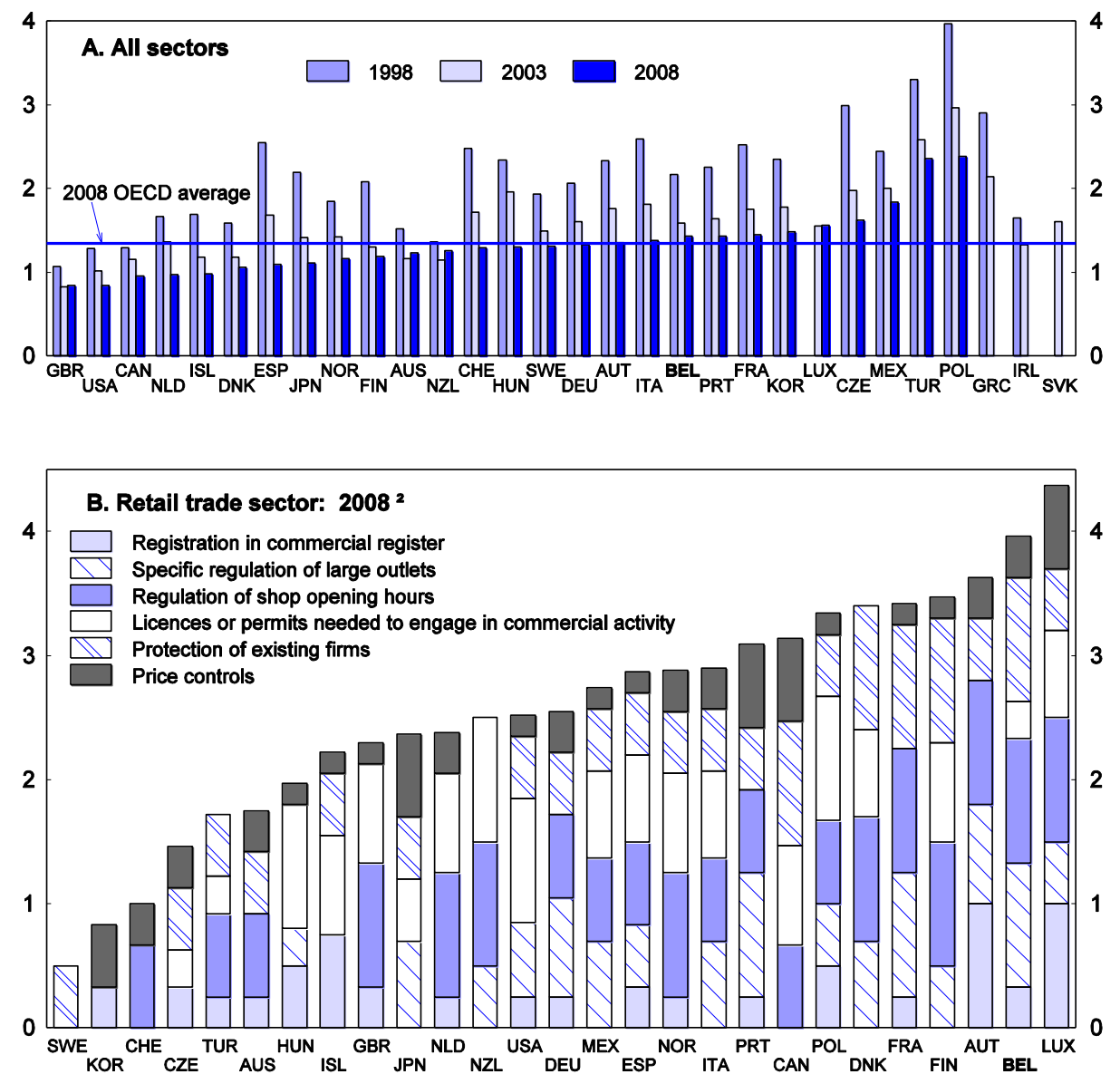

1. Wölfl, A., I. Wanner, T. Koźluk and G. Nicoletti (2009) "Ten years of product market reform in OECD countries - insights from a revised PMR indicator", OECD Economics Department Working Paper, No. 695 and in Conway, P. and G. Nicoletti (2006), "Product Market Regulation in the Non-Manufacturing Sectors of OECD Countries: Measurement and Highlights", OECD Economics Department Working Papers, No. 530.

2. No data for Greece, Ireland and Slovak Republic.

Source: OECD, PMR database. 


\section{Box 1. The new competition and law enforcement framework}

The competition framework was reformed in 2006 after the Court of Audit (Cour des Comptes) had found that the previous setup produced little enforcement and that procedures took too long. The competition authorities were tied down in mandatory merger reviews with few resources for other competition matters. Out of nearly 200 matters between 1993 and 2005, barely a third resulted in a decision, and only one resulted in a fine. Most investigations were taking more than 2 years to complete, excluding cases that expired instead of having a formal closure decision. In matters other than interim measures and mergers from 1997-2001, the Council reached only one decision per year and the average time for cartel infringement proceedings was over six years. The Court of Audit found that the principle reasons for this state of affairs were, in addition to the resource requirements of the mandatory merger reviews, poor organization and the lack of support for a coherent policy of protecting competition to promote economic efficiency. The new competition law tracks the EU legislation based on the prohibition of anti competitive restrictive agreements and abuses of dominant positions and gives a legal basis for leniency. In addition, the latest EU substantive standard for mergers, which is based on the concept of a "substantial impediment to effective competition," rather than solely a "dominance" test, is incorporated in the law. The reform did not introduce changes to the fines which can be imposed by the Authority, which can be as high as $10 \%$ of annual turnover. Staff at the Competition Authority is about 70 person years, which is the same as Switzerland, but less than in the Netherlands and the Nordic Countries.

The 2006 reforms also modified the institutional structure. The Belgian Competition Authority is not a single integrated agency but a so-called "dual authority". It has two principal parts, the Competition Council and the Directorate General for Competition. The Council includes the general assembly of the Council (in a narrow sense), which is the decision making body for competition enforcement. The law authorises six full time and six part-time members (councillors), who are appointed by the government for six-year, renewable terms. The College of Competition Prosecutors (with a statutory maximum of ten members) is attached to the Council. The competition prosecutors initiate and direct investigations and present enforcement matters to the Council and rely upon the staff of the Directorate General for Competition for investigative and other support. There is therefore institutional separation between the investigation, prosecution and decision making powers within the authority. Unlike in some other countries, the Competition Authority is not responsible for consumer protection, which is the responsibility of the Directorate General for Market Regulation under the same ministry. There is also an advisory Commission for Competition in the Central Council for the Economy.

Merger review procedures require advance notification and approval for transactions that involve a total turnover in Belgium of over EUR 100 million (and at least two of the undertakings concerned have turnover in Belgium exceeding EUR 40 million). These thresholds are more than twice the limits in the pre-reform procedures, inducing a substantial reduction in merger reviews. The competition authority is not fully independent in this area as the government can override a Council decision rejecting a merger allowing it to go forward "for reasons of general interest which outweigh the risk of competition." It may also overrun any conditions imposed on the merger by the Competition Council. In particular, the Council of Ministers may consider matters of national security, international competitiveness, employment and consumer interests. This provision has not been used to date. The leniency programme was updated in October 2007 to make it consistent with now standard European practices, so a cartel member may be fully or partly exempted from sanctions for bringing the cartel to the attention of the enforcement authority, bringing in evidence the authority did not have, or admitting participation.

In the first full year under the new competition regime (2007), the Council reached three cartel infringements decisions and considered six applications for leniency. In the second year, the number of decisions on cartel infringements rose to five and six applications for leniency were considered. The first cartel fine (of slightly below EUR 500 000) ever imposed under Belgian law was in early 2008 in a case that started with a leniency application. The relatively small fine reflects that the cartel ended in 2002 and the smallness of the market. A recent decision illustrates the importance of the recent changes to the statute. In July 2008, the Council ruled against a trade association "ethical" rule setting minimum fees (for interior designers), but could not impose a fine because the law in effect during the period of the violation, from 2002 to 2005, did not authorise fines against an association. Other small fines have been issued to trade associations to signal that co-ordination dampening price competition will no longer be acceptable.

The Competition Council may end up with important functions in regulatory matters. As is usual elsewhere, it already acts in co-operation with sector regulators. Under the competition law, the Competition Council may also be empowered to decide appeals from decisions of sectoral regulators. This function will depend upon enactment of corresponding authorizations in the sector regulatory laws. The Directorate General has engaged in policy advocacy by issuing reports or opinions on taxicab regulation, real estate and interlocking directorates. 
Figure 2. Comparative price levels ${ }^{1}$

2007, EU15 = 100

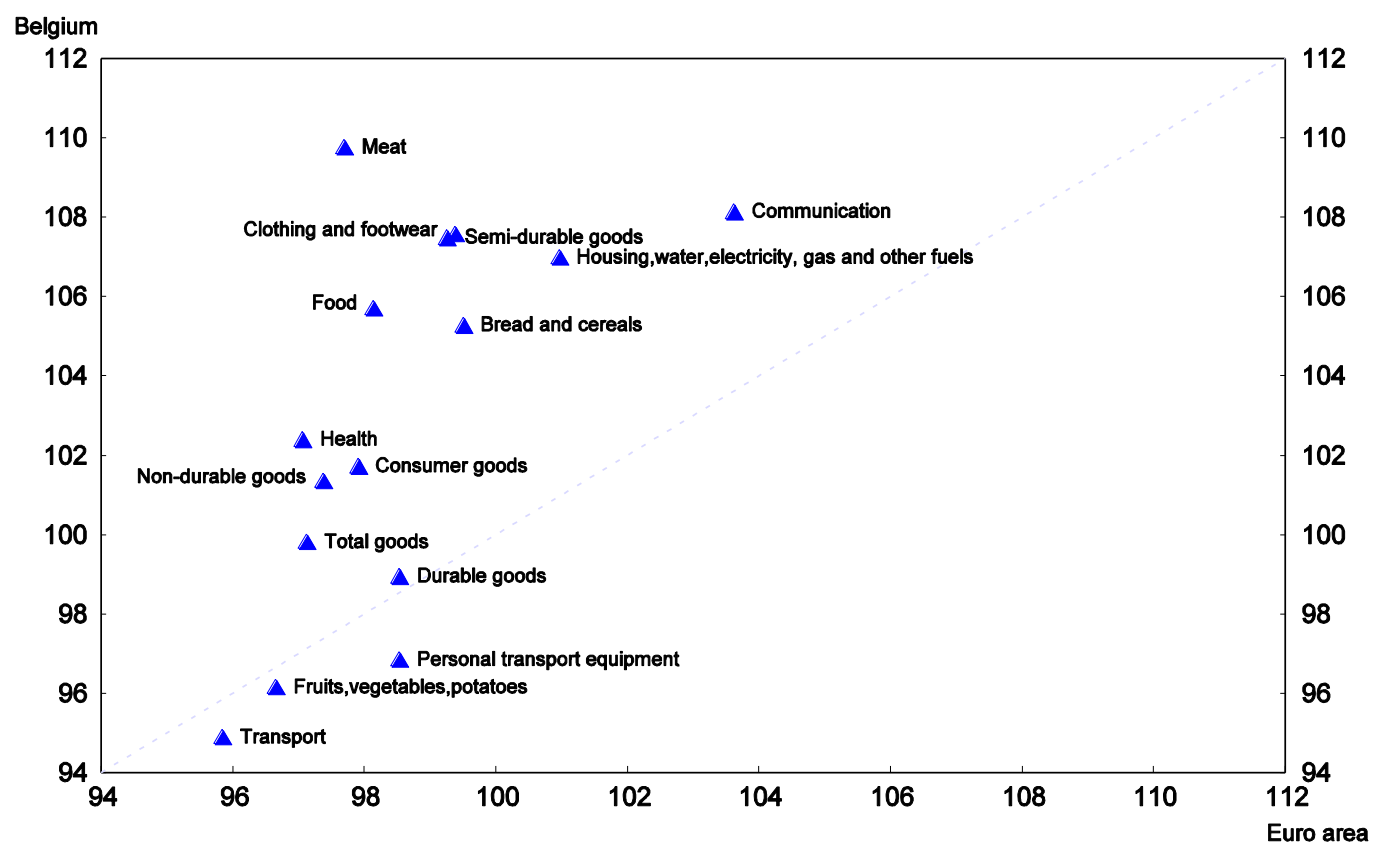

1. The PPPs are divided by the current nominal exchange rate to obtain a price level index (PLI) which expresses the price level of a given country relative to another, or relative to a group of countries like the EU15.

Source: Eurostat database.

4. Although the independence of the Competition Authority has been strengthened (it is now financed through a separate line in the government's budget), the investigative part of the Authority continues to be a Directorate General inside the Ministry of Economy. The Directorate's resources remain largely determined by the federal government and a number of supporting costs (location, information and communication technology, etc.) are provided by the Ministry outside the budget line. Thus, the Competition Authority applies the centralised hiring procedures of the civil service and it remains physically located in the Ministry's building. Furthermore, the large backlog of old cases has led to problems in meeting legal deadlines and has forced the College of Prosecutors to prioritise cases. This has been done based on criteria, the origin of which have not been made sufficiently clear to the wider public, and may lead to accusations that political priorities affect the ranking of cases. Therefore, the situation should be monitored, in particular regarding the authority's degree of independence and accountability. If necessary, a potential improvement would entail giving the authority a status of a fully independent agency with a complete budget decided by the parliament and granted full freedom in hiring. In terms of improving the authority's perceived independence, physically moving out of the Ministry building and enhancing the transparency of the selection of the prioritisation criteria may be considered. Despite the reinforcements made in the past years, there are still signs the Competition Authority may be in need of additional resources. The current staffing may be reconsidered as it appears on the low side when compared with other small economies such as the Netherlands and the Nordic countries (Høj, 2007), and it has not proved sufficient for dealing with the large amount of old cases and court appeals against its decisions and for assuming a more proactive role. 
5. There is a need for strong signalling of the Competition Authority's determination to enforce competition law. The fines imposed up to date have not been particularly high. However, in the future the Competition Authority will inevitably be dealing with larger cases in crucial sectors and the use of high fines will be desirable in order to signal the tough stance against infringements and to deter future uncompetitive practices. High fines will also increase the incentives to apply for leniency thereby facilitating the policing of cartels. Deterrence would be enhanced by introducing criminal sanctions such as prison sentences for hard-core cartel infringements. To enhance the Authority's effectiveness, clear and efficient communication procedures (in particular regarding confidential information) between the Authority and the sectoral regulators are essential. Finally, plans to establish the Council as the sole institution for appeal against sectoral regulator decisions are commendable. This is the case in many OECD countries, as the Council is well placed to rule on competition cases in the network sectors. If this is to increase the speed with which cases are settled it may imply the Council will need additional resources.

6. The notable progress in the reform of the Competition Authority does not appear to be coupled with comparable developments in the regulation of the network sectors (see the sections below). In order to fulfil the government's goal of stimulating economic activity and improving consumer welfare through the strengthening of competition in Belgian markets, a determined approach to competition policy needs to be implemented and enforced at all levels of regulation (SPF Economie, 2008). The government has recently created a price observatory which will aim at increasing the price transparency in the market, but care should be taken in order not to further complicate the regulatory structure and to minimise the risk of this authority becoming a price setter.

\section{Competition in retail distribution is burdened by heavy regulation}

7. The retail sector in Belgium is characterised by a relatively large number of small shops (Figure 3), a structure that may have a number of advantages in terms of accessibility. However, at the same time, the employment share of the sector is below the average of the OECD countries (Figure 4, Panel A) pointing to a relatively large scope for jobs creation. Moreover, productivity in the sector has been growing slower than in most OECD countries (Figure 4, Panel B and Biatour and Kegels, 2008). ${ }^{3}$ Finally, the price levels of many of the goods associated with retail distribution are notably higher than in other euro area countries (Figure 2). At the same time, the sector is much more regulated than in most other OECD countries, especially in the areas of protection of existing firms, specific regulation of large outlets and shop opening hours (Figure 1, Panel B). This regulation shields existing shops from competitive pressures which in many cases leads to the protection of local monopolies (Høj et al. 1995 provides evidence on the relation between regulation, prices and size of shops). Therefore, deregulation of retail distribution can be expected to boost productivity. This conclusion is backed by the results of OECD simulations, which show that Belgium is among the countries with the highest potential gains from the liberalisation of the retail sector (Box 2). Hence, as retail trade is an inherently competitive sector, scaling back the regulation should benefit consumer welfare. A number of studies have shown that lowering entry barriers can increase the efficiency of retail trade leading both to lower prices (Pilat, 1997, Haffner and van Bergeijk, 1997) and higher employment (Bertrand and Kramarz, 2002; CPB, 1995; Creusen et al, 2006). The scope for the increase in employment in the sector should not be overlooked in the

3. Although labour productivity growth in the Belgian distribution sector (which consists of wholesale and retail trade and repair shops) has been slow in the past decades, there are findings that the actual level of productivity in Belgian distribution is among the highest in the OECD (Inklaar and Timmer, 2008). The main reason for the low productivity growth is the low growth rate of total factor productivity. The high productivity levels are due to very high capital intensity (both information and communication technology capital and other types of capital). This may seem somewhat in contrast with the fact that the Belgian retail sector is characterised by a large amount of small shops. Partial explanations for this phenomenon may include the wide definition of the sector, encompassing far more than just retail trade and the relatively restricted opening hours (due to opening hour regulation and working hour regulation). 
Belgian context, given the fact that these are likely to be jobs for low skilled workers and for flexible part-time workers, such as females returning to the labour market.

Figure 3. The retail sector is characterised by a large share of small shops 2003-2005 averages $^{1}$

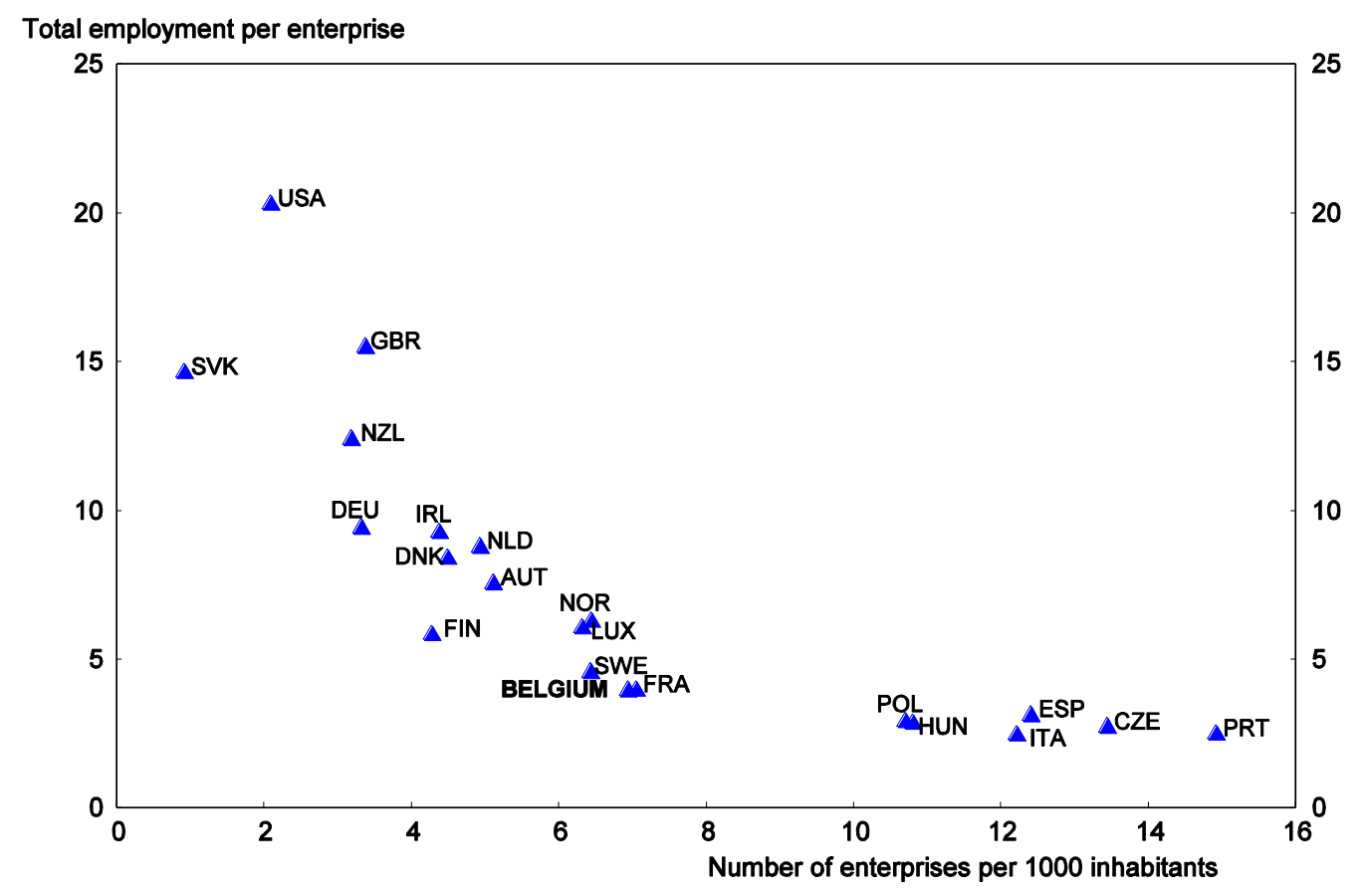

1. 2003-2004 averages for United States and Czech Republic, 2004-2005 for Sweden.

Source: OECD, Structural Business Statistics database.

8. Box 3 provides a detailed overview of the main restrictions to competition in the Belgian retail sector, which generally protect existing shops, in particular those of smaller size, from the entry of new innovative business models. The prohibition of sales below costs prevents retailers from easily selling unwanted stocks, increasing the risk for new entrants. The ban on announcements of price reductions before sales periods ("the black-out period") reduces consumers access to information on prices, while the prohibition of tied sales (better known in Belgium as "joint-sales") inhibits the diffusion of innovative products or new technology (in April 2009 the European Court of Justice declared this law as incompatible with European legislation). The government is currently working on the modification of most of the above regulation. The changes proposed so far do not appear substantial. As the Competition Authority should deal with the abuse of dominant position, the restrictions on prices and assortment should be scrapped altogether. In order to improve consumer welfare, providing consumers with the possibility of shopping outside standard hours and the retailers with flexibility to better meet consumer demand, the shop opening hour regulation, which is among the more restrictive in the OECD, should be abandoned. Finally, zoning regulation for large outlets, which was reformed in 2005 resulting in a faster decision making process, should be restricted to issues of urban planning, transport and safety (in line with the recent recommendation from the Ministry of Economy, SPF Economie, 2008). This would allow market forces, rather than a nation-wide committee with a strong representation of existing retailers or the local municipality, to decide on the consumers' benefits arising from a new retail outlet. 
Box 2. Anti-competitive regulation and labour productivity - OECD simulations

OECD calculations report that aligning sectoral regulation (in retail trade, electricity and gas and professional services) with international best practice would boost labour productivity in the entire economy by nearly $16 \%$ over the next decade. Reforms in the retail sector only, could raise productivity by almost $12 \%$ if regulation was brought in line with OECD best practice. Similarly, for reforms in the energy sector, productivity is calculated to increase by $3.5 \%$, which is well above the average of the countries analysed (Table 2).

Table 2. The simulated effect of liberalisation on labour productivity in the future

Simulated percentage increase in productivity over 10 years

\begin{tabular}{|c|c|c|c|c|c|c|}
\hline & \multicolumn{6}{|c|}{ Sectors simulated } \\
\hline & \multicolumn{2}{|c|}{ All sectors } & \multicolumn{2}{|c|}{ Electricity and gas } & \multicolumn{2}{|c|}{ Retail } \\
\hline & & & Degree & reform _ & & \\
\hline & $\begin{array}{c}\text { To } 2007 \\
\text { best practice }\end{array}$ & $\begin{array}{l}\text { To EU 75th } \\
\text { percentile }\end{array}$ & $\begin{array}{l}\text { To } 2007 \text { best } \\
\text { practice }\end{array}$ & $\begin{array}{l}\text { To EU 75th } \\
\text { percentile }\end{array}$ & $\begin{array}{l}\text { To } 2007 \text { best } \\
\text { practice }\end{array}$ & $\begin{array}{l}\text { To EU 75th } \\
\text { percentile }\end{array}$ \\
\hline Belgium & 15.8 & 15.6 & 3.5 & 3.5 & 11.9 & 11.7 \\
\hline Netherlands & 8.3 & 7.4 & 3.2 & 2.8 & 4.8 & 4.3 \\
\hline France & 10.3 & 10 & 1.4 & 1.3 & 7.4 & 7.2 \\
\hline Denmark & 8 & 7.3 & 2.6 & 2.3 & 5.4 & 5.1 \\
\hline Italy & 14.1 & 13.7 & 2.6 & 2.5 & 4.9 & 4.8 \\
\hline Canada & 14.4 & 14.1 & 5.6 & 5.5 & 7.8 & 7.6 \\
\hline Finland & 6.8 & 6 & 2.1 & 1.8 & 4.2 & 3.9 \\
\hline Portugal & 12.2 & 11.8 & 3.8 & 3.6 & 7.2 & 6.9 \\
\hline Spain & 13.9 & 13.8 & 4.5 & 4.5 & 10.9 & 10.8 \\
\hline Total & 11.4 & 10.9 & 2.6 & 2.6 & 6.9 & 6.4 \\
\hline
\end{tabular}


Figure 4. Belgian retail is characterised by low employment, low productivity growth and strong regulation
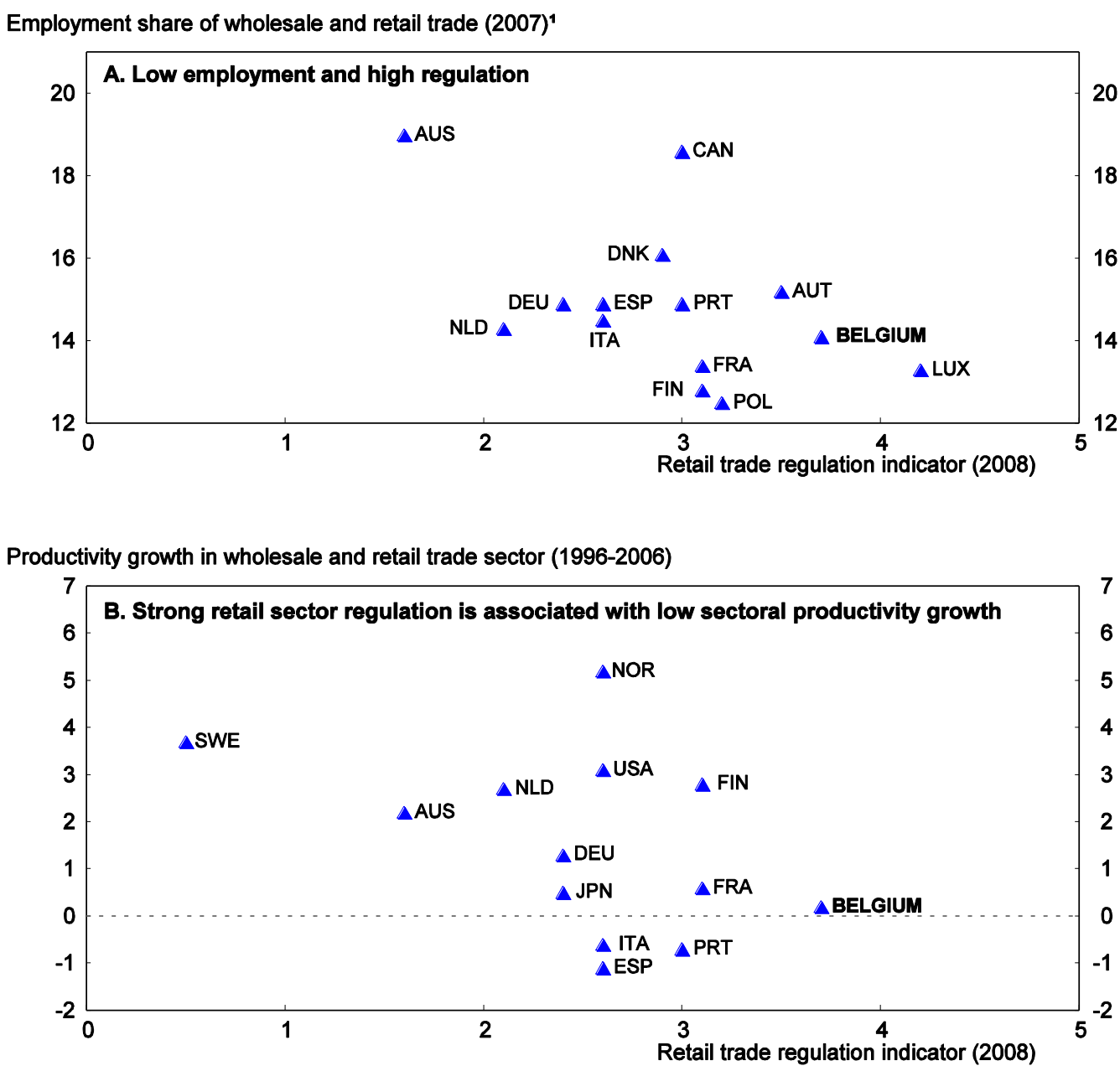

1. 2006 for Australia, Hungary, Ireland, Portugal and Spain. The number of observations is limited by data availability. Source: OECD, PMR database, STAN database and OECD calculations. 


\section{Box 3. Examples of competition restricting regulation in retail distribution}

\section{Price and transparency control}

- $\quad$ Sales below costs are prohibited outside the sales season or liquidation of the outlet and the sale season is limited to two periods of one month each year.

This type of regulation limits retailers' flexibility and reduces their ability to get rid of unwanted stock, thereby constituting an implicit deterrent to entry and reducing consumer welfare. Moreover, the definitions of costs and minimum margins are cumbersome and the verification problematic, especially for start-ups with no history of costs.

- Announcements of price reductions within 6 weeks before the sales period are prohibited ("the black-out period"). It is also prohibited to announce reductions which are to take place during these 6 weeks.

The black-out period legislation reduces price transparency and impedes the consumers' access to a full set of price information for their choice.

- $\quad$ Tied sales of products are prohibited.

This regulation aims at disallowing the cross-subsidising of products (or products and services), to enhance transparency. It protects smaller retailers who may have less scope to offer products tied together and has notably increased the complexity of retail regulation. Many exceptions have been granted, for example for the sale of an ensemble (e.g. frames with lenses) or for the sale of a product together with its packing. As the notion of an ensemble is unclear a priori, the law increases uncertainty for new products and hampers the diffusion of new technology.

\section{Regulation of opening hours}

- $\quad$ Shops may be open on weekdays between $5 \mathrm{~h}$ and $20 \mathrm{~h}$, on Fridays (and days preceding holidays) till $21 \mathrm{~h}$. They have to be closed for one period of 24 hours a week (by default Sundays, though any day of the week can be chosen as long as it is kept the same for at least six months.) The law allows for an additional opening during 6 Sundays a year.

- Exemptions include: small shops linked to gas stations, night shops (under 150m2, selling groceries and hygienic materials may be open $18 \mathrm{~h}-7 \mathrm{~h}$ ) and shops in designated tourist areas.

- The law foresees fines, shop closure and prison penalties for infringement and is enforced by state officials.

Restrictions on shop opening hours protect existing retailers, in particular small night shops, against new innovative business models. Such regulation also limits the retailers' ability to adjust to changes in consumer demand and hurts consumer welfare by reducing the ability to choose when to do shopping. In Belgium, such regulation is aimed at enhancing workers' welfare despite its potential employment-reducing effects.

\section{Regulation of large outlets}

- The location decision is based on the evaluation of four types of possible effects: $i$ ) spatial effect (urban planning, access and road safety); ii) on consumer interests (product range and prices); iii) on employment (gross and in existing commerce); and iv) on the balance between small, medium and large commerce.

- Decisions for shops between $400-1000 \mathrm{~m}^{2}$ of surface are taken by the municipality, while for shops above $1000 \mathrm{~m}^{2}$ the National Economic and Social Committee for Retail has to be consulted. In case of surfaces above $2000 \mathrm{~m}^{2}$ the neighbouring municipalities have to be consulted.

- The Economic and Social Committee is composed of representatives of ministries, regions, consumer associations, labour organisations, independent retailers and SME's and integrated commerce.

- The decision must be made and communicated within a maximum of 75 days and can be appealed against to the Inter-ministerial Committee for Retail (Comité Interministériel pour la Distribution). Silence is consent.

Zoning regulation may be desirable due to issues of urban planning, traffic congestion and security, but is often used to protect existing retailers against new entrants. As emphasised in OECD (2008), the evaluation of consumer interests should be left to the consumers themselves, who will ultimately decide whether the new business serves them better than the existing ones through their shopping choices.

\section{Other regulation}

- $\quad$ Further strict regulations concern advertising, specific retail sectors (e.g. pharmaceuticals) and sales at the home of the customer. 


\section{Regulators in network industries are faced with dominant positions of incumbents}

9. The liberalisation in the network sectors remains limited. The degree of opening is patchy and the diversity of regulatory structures complicates regulation (Box 4). There exists no uniform definition of regulatory bodies. The role of network sector regulation and the lack of coordination between the sectoral regulators and the Competition Authority have been identified as the most serious issues of the design of the Belgian system (SPF Economie, 2008). Another important issue concerns the unusually wide scope of universal services which poses a barrier to entry and the expansion of competitors, while benefiting the incumbents due to problematic schemes for financing. The universal service obligations (USOs) are summarised in Box 5 and their effect on competition is discussed below.

\section{Box 4. Regulation of network sectors}

The regulation of network sectors in Belgium differs substantially across the individual sectors. In general, the Competition Authority deals with the cases of the abuse of dominant position and cartel pricing in competitive sectors and the competitive segments of the network sectors. Non-discriminatory third party access to monopoly segments is the competence of sectoral regulators which have various structures and varying degrees of independence from the executive and different sources of financing. The network sector regulators are usually also in charge of issuing market entry licenses, assuring universal services and having some advisory tasks as regards sector strategies.

The energy sectors (electricity and gas) are regulated by a single federal authority, the Commission for Electricity and Gas Regulation (known by its French and Flemish abbreviation CREG), and three regional authorities. The federal regulatory tasks concern mainly the approval of transmission and distribution tariffs (in both gas and electricity) and advising the government in the other segments of the markets. In the electricity market, its regulatory powers are limited to transmission and distribution networks above a certain threshold (70kV).

The federal authority's independence seems in line with OECD best practice: CREG has its own budget which is funded through a surcharge on customer utility bills securing it from potential political intervention, although the management remains nominated by the government. On the other hand, regional regulators are responsible for appointing distribution network operators in gas and distribution grid operators in electricity, issuing retail supply licenses, ensuring the implementation of universal service obligations and advising the regional governments. The independence of the regional regulatory authorities from the sub-national levels of government does not seem as well assured as in the case of the federal regulator.

In principle, sub-national level regulators may be better prepared to deal with regional regulatory tasks as they may be better prepared to deal with issues of local distribution and supply as well as consumer needs due to their local knowledge and relative proximity to the final market. However such a structure may cause problems of regulatory powers (overlap of powers, lack of regulatory coverage of certain segments, lack of economies of scale) and coordination (both of the objectives and of enforcement decisions). This structure may lead to lengthy communication procedures and increase bureaucracy. Three regulatory environments are an additional entry cost for competitors and this structure has been frequently criticised (IEA, 2006). One of the effects of the set-up was the different progress in the legal opening of the electricity market for consumer choice, which was functional in Flanders in 2003, while taking until 2007 in Wallonia and the Brussels-Capital region.

The telecommunication and postal sectors are regulated by the Belgian Institute for Postal Services and Telecommunication (BIPT). The regulator's independence was strengthened in 2003, formerly being part of the Ministry which executed ownership powers in the incumbent. Financing is assured mainly through licensing fees. Despite the improvement, some controversies about the issue of independence remain: the members of the Council (decision making body), including the head, are nominated and can be dismissed on the proposal of the executive. There remains some uncertainty about the possibility of the government to overturn BIPT decisions and about the political influence on the regulators priorities (Platform, 2007). Contrary to the energy markets, the regulatory tasks are concentrated in a federal body; however there seems to be pressure from the language-Community level regulators (who have competencies over broadcasting content) to gain regulatory powers over infrastructure common to broadcasting and telecommunication (e.g. internet). In 2006, these resulted in a cooperation agreement which laid down the procedures for resolving disputes of joint competencies, causing some concern due to the increased scope for bureaucratic consultation and leaving decision power over unresolved issues at the ministerial level, thereby somewhat weakening the regulator. In November 2008, the federal government proposed measures to strengthen the regulator: the procedure for imposing a fine is to become easier, and fines may become higher. BIPT is to acquire more powers for intervention in the market. In the cases that occur, its defence before the Court of Appeal is to become less elaborate. 


\section{The energy sector: strong incumbents and high implicit barriers to entry}

\section{Electricity}

10. The liberalisation of the energy market essentially began in April 1999 with the transposition of the first EU electricity and gas directives. The second EU directives were transposed in June 2005 while the electricity market for households was fully legally opened on $1^{\text {st }}$ June 2003 in Flanders. Wallonia and Brussels-Capital followed on $1^{\text {st }}$ January 2007 when supplier choice was granted to all consumers. Despite the liberalisation, electricity prices remained well above those in OECD countries with the most competitive electricity markets (Figure 5). Moreover, energy prices have been found to contribute strongly to the large positive inflation differential between Belgium and the euro area in late $2008 .{ }^{4}$

11. Historically, all segments of the electricity market have been concentrated in the hands of Suez and Gaz de France. Following their merger, the companies agreed with the European Commission to reduce their involvement in certain segments (Box 6). However, most of the segments of the market are set to remain highly concentrated in the hands of the merged company GDF-Suez. As now only legal separation of the transmission operator and accounting separation of other segments are required, the government's efforts to strengthen separation, including a favourable stance towards the introduction of ownership separation of transmission network operators are commendable. Notably, the government has taken steps to encourage auctioning off some of the incumbent's spare capacity which are yielding results (for example in late 2008 the incumbent agreed to sell $10 \%$ of Belgian production capacity) and efforts to introduce new players should therefore be continued. Nonetheless, a number of additional barriers to entry should be removed in order to encourage new competitors as the sector remains burdened by more competition-restricting regulation than international best practice (Figure 6, Panel A). The wholesale exchange pool, established in 2006 , has failed to play a significant role (in 2008 , only about $13 \%$ of daily electricity consumption was traded on the day-ahead market ${ }^{5}$ ), despite that such a measure has proven beneficial for competition in a number of OECD countries. The lack of liquidity and high prices on the wholesale market have deterred entry in the supply market and therefore further efforts to increase interconnection capacity is desirable to enhance competition. Moreover, although the retail electricity prices are not regulated, most suppliers choose to use a variation of a cost indexation formula calculated by the federal regulator (CREG), which was used historically to determine the regulated price before the markets were liberalised. The publication of the components by CREG should be ceased, as they bring little value added while posing the risk of the regulator acting as a price coordinator on the retail market. As this formula is based, among others, on the Zeebrugge hub spot gas price and available nuclear plant capacity, both of which can be strongly influenced by the incumbent companies, increased vertical separation in the market should ensure this is not the case. The transmission and distribution tariffs are accompanied by high uncertainty, undermining potential new business models of new entrants. Switching to multi-annual tariffs for transmission (in 2008) and distribution (in 2009) are significant steps towards a more stable environment, however the legal uncertainty related to the details of the introduction of such

4. The favourable development in 2007 has been due to a transmission and distribution tariff decrease imposed by the federal regulator, which was later annulled by the court on the grounds of the regulator exceeding its competencies. The decreases of electricity (and gas) prices in 2007 relative to other countries have been reversed as a result of the tariff increase ranging from below $10 \%$ in Wallonia (where they remain the highest) to almost $50 \%$ in Flanders (where they still remain the lowest). This caused final energy prices to increase sharply. The $22 \%$ inflation (year-on-year) of Belgian energy prices in September 2008, is estimated to have been only $13 \%$ if not for the change in distribution tariffs, and below $8 \%$ (in line with Euro area average) if additionally capacity was kept at 2007 levels. Of the 1.8 percentage point differential in headline inflation between Belgium and the euro area (September 2008) 1.2 percentage points can be explained by gas and electricity price increases (NBB, 2008).

5. Monthly variation can be considerable, e.g. in May 2008 the traded volumes reached a third of Belgian demand. 
legislation has, so far, undermined its effect. Another example of the uncertainty surrounding tariffs was when the lowering of tariffs by CREG led to an appeal against its decisions and its subsequent annulment in 2008. This resulted in a number of suggestions that the regulator needs additional tariff-setting powers in the distribution segments (NBB, 2008).

Figure 5. Electricity and gas prices

Pre-tax
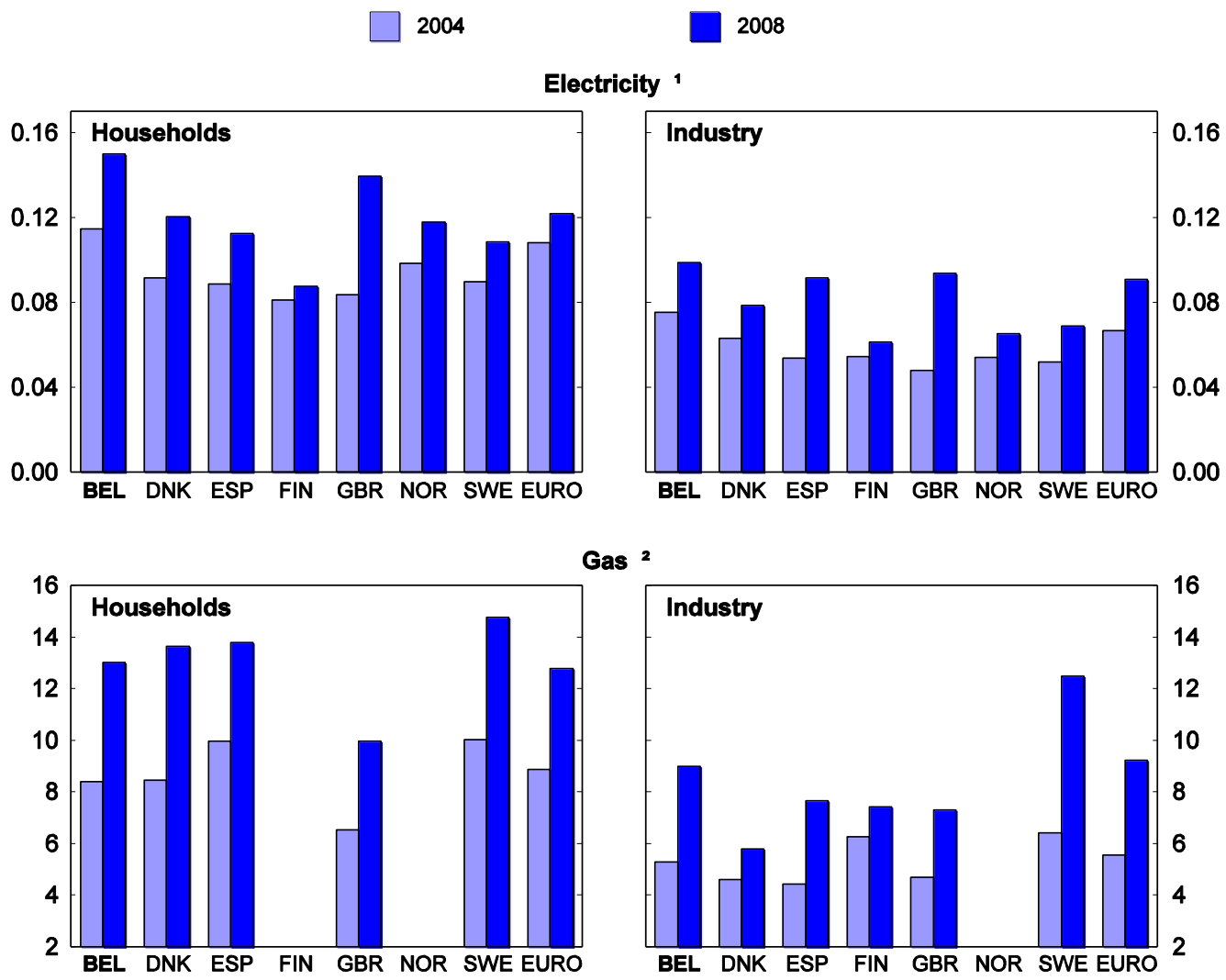

1. Euros per kWh, medium consumption.

2. Euros per gigajoules, medium consumption. 2007 for Denmark.

Source: Eurostat database.

12. Another potentially important deterrent to entry is the complicated regulatory structure (Box4) which effectively divides Belgium into three separate energy markets, thereby increasing entrants' (fixed) costs. The federal regulator seems sufficiently independent and equipped to regulate the areas within its competence. In April 2008, the government increased the investigative powers of its officials and thus improved the toolset of the federal regulator. However, the set-up of the regional regulators does not seem as well developed. Firstly, their independence does not seem as well secured, as they are financed directly by regional government budgets, while the senior staff is appointed by the regional government, and their objectives are not necessarily in line with each other nor with those of the federal body. Secondly, although regional regulators in downstream segments may, in principle, be better equipped to fulfil their tasks, being closer to the final consumer, such a structure risks unnecessary bureaucratic delays in communication and 
the loss of economies of scale, in particular in the Belgian context where divided regulators are dealing with a very concentrated market. In addition, there is a risk that regional regulators may be more prone to regulatory capture, in particular given their weak independence from the governments and the strong involvement of municipalities in distribution networks. ${ }^{6}$ Therefore the regulatory structure should be revisited and the regulatory tasks should be concentrated in one authority. As a second best, strong independence and sufficient powers of the regional regulators need to be secured, while the current voluntary dialogue forum should be replaced by a binding co-operation and co-ordination framework between regulators of all levels is necessary and to align their priorities. Finally, universal service obligations appear overly broad and may deter entry due to a higher cost of adapting to the regional specificities (Box5). In order for them not to constitute a barrier to new competitors, regional authorities wishing to conduct additional social policy based on energy provision, should purchase energy within their own budget or use transfer policies instead of the regulated tariffs.

\section{Gas}

13. Gas is imported mainly through the Zeebrugge hub and LNG terminal. Roughly one half of the households use gas for heating and cooking and the role of gas in the generation of electricity, is set to increase significantly over the coming two decades (IEA, 2006). A number of issues concerning the gas sector are also common to the electricity sector, and thus have already been discussed in the previous section. The sector was liberalised in a similar time frame as the electricity sector. Gas prices were generally near the EU average until 2007, but as in electricity the subsequent fall was due to a regulatory lowering of tariffs, which were annulled in 2008 (Figure 5).

14. The main regulatory problems in the gas market concern high implicit barriers to new entry and the resulting strong position of the incumbent, while explicit entry barriers are low (Figure 6, Panel B). The gas market is highly concentrated (GDF and Suez) and the commitments accompanying the merger of the two companies are unlikely to improve the situation (Box 6). As a result, the transmission network capacity has been, to a large extent, unavailable to new entrants as it was contracted out for very long time periods. Measures to resolve this situation have been imposed by the Commission in late 2007 (EC, 2007a and 2007b) however it will take time to evaluate whether they are sufficient. Moreover, installing a well functioning wholesale pool for natural gas, which has proved to benefit competition in a number of OECD countries, is recommended. ${ }^{7}$ Given the strong position of GDF-Suez in various segments of both the gas and electricity markets, regulatory efforts should be increased to ensure that the legal interdiction of cross-subsidisation within the same company, both between the different segments of the gas market as well as between gas and electricity products, is respected. As in electricity, the law currently requires legal separation of the transmission and distribution segments and accounts separation of the other segments. The introduction of mandatory vertical ownership separation between different segments or of strengthening the existing formal separation, in line with the government's proposals, would be a desirable step. In this light, the government should continue its efforts to make sure that the main market players do not have a blocking minority participation in the ownership structure of the Zeebrugge hub and the LNG terminal. This should be done with the goal of assuring non-discriminatory third party access to the terminals and to transmission capacity from the terminals, which has proven a serious problem in the past. The Ministry of Energy is currently working on this issue, as part of the new Code of Conduct on third party access to the gas network.

6. The municipalities have a legal monopoly in electricity distribution, and nearly all of them transferred the distribution to inter-municipal companies (intercommunales). The income from the energy-related activities constitutes an important figure in the municipal budgets reaching $10 \%$ of the revenues.

7. Although APX Zee (a within-day and day-ahead gas trading platform) already exists, its role is negligible with a total of 33 transactions done in the whole of 2008, of which 11 since February. 


\section{Box 5. Universal services in energy, telecoms and post}

Universal service obligations (USOs) are intended to assure the universal access to a designated service at a specified quality and an affordable price. In practice however, they may serve as a barrier to deter new entrants, securing of an incumbent's position or a subsidy for the latter. In general each World Trade Organisation member has the right to set the desired scope of USO. The specific rules for EU member states are set out in the Universal Service Directive (for telecoms) and in the Postal Directive. In general USO's, if constituting a cost to the supplier, must be compensated for with profits made in other markets. They can be financed directly from the government budget (through the acquisition of a service), from a fund to which market participants contribute (e.g. pay or play fund) or through a designated segment of the market (e.g. through the reserved area in postal services, through distribution tariffs in distribution).

In Belgium no uniform approach to universal services exists. While provisions for auctioning off some of the services to the provider with best offers exist, other services are imposed on all operators. The scope of universal service tends to be unusually broad in all sectors while differing across regions (Table 3).

\section{Table 3. Universal service obligations in Belgium}

By network sector

\begin{tabular}{|c|c|}
\hline Sector & USO \\
\hline \multirow[t]{2}{*}{$\begin{array}{l}\text { Energy (electricity } \\
\text { and gas) }\end{array}$} & $\begin{array}{l}\text { - } \quad \text { Social tariffs for low income households. } \\
\text { - } \quad \text { Free annual electricity quota for all Flemish households. } \\
\text { - } \quad \text { Arrangements for households unable to pay bills. } \\
\text { - }\end{array}$ \\
\hline & $\begin{array}{l}\text { USO's are regional competencies, thus the scope differs across regions. The federal } \\
\text { regulator incorporates the regional specificities of USO's into the individual network } \\
\text { distribution tariffs. }\end{array}$ \\
\hline \multirow[t]{2}{*}{ Telecoms } & $\begin{array}{l}\text { - } \quad \text { Access to the infrastructure of fixed line telephony (at an affordable price). } \\
\text { - } \quad \text { Provision of public phone booths over the entire national territory. } \\
\text { - } \quad \text { Publication of universal white pages. } \\
\text { Application of social tariffs for disabled and elderly/low income (fixed and mobile). }\end{array}$ \\
\hline & $\begin{array}{l}\text { Since } 2007 \text { the government has implemented tendering procedures in order to } \\
\text { designate the provider of each of the first four services. There are no procedures for } \\
\text { tendering social tariffs as these are imposed on all providers and funded through a fund to } \\
\text { which all market participants contribute. There are no legal tools to assess that the } \\
\text { USO provision actually constitutes an unfair burden, which would justify the additional } \\
\text { financing. The European Commission has launched an infringement procedure and has } \\
\text { recently taken Belgium to the European Court of Justice. }\end{array}$ \\
\hline \multirow[t]{2}{*}{ Post } & $\begin{array}{l}\text { - } \quad \text { Daily collection and delivery, sorting and transport of letters and parcels within a size } \\
\text { - } \quad \text { Mimit. } \\
\text { - } \quad \text { Handling of one access point per municipality mail. } \\
\text { - } \quad \text { Early delivery of newspapers and certain periodicals. } \\
\text { - } \quad \text { Manouse payments of pensions and financial post services. } \\
\text { - } \quad \text { Printed election material delivery at reduced rates. }\end{array}$ \\
\hline & $\begin{array}{l}\text { USOs are provided by the incumbent in return for proceeds from the reserved } \\
\text { segment of the market. The law foresees a possibility of financing USO costs from a fund } \\
\text { paid by all license holders which, although not used, increases the uncertainty of the legal } \\
\text { environment. The first two services are rather standard in other countries, while the others } \\
\text { are Belgian-specific. }\end{array}$ \\
\hline
\end{tabular}

Source: OECD and European Commission (2006), "Commission staff working document SEC(2006) 445", Impact assessment report, annex to the report regarding the outcome of the Review of the scope of universal service in accordance with article 15(2) of Directive 2002/22/EC. 
Figure 6. Competition restricting regulation in energy and telecommunications 2008 Indicators
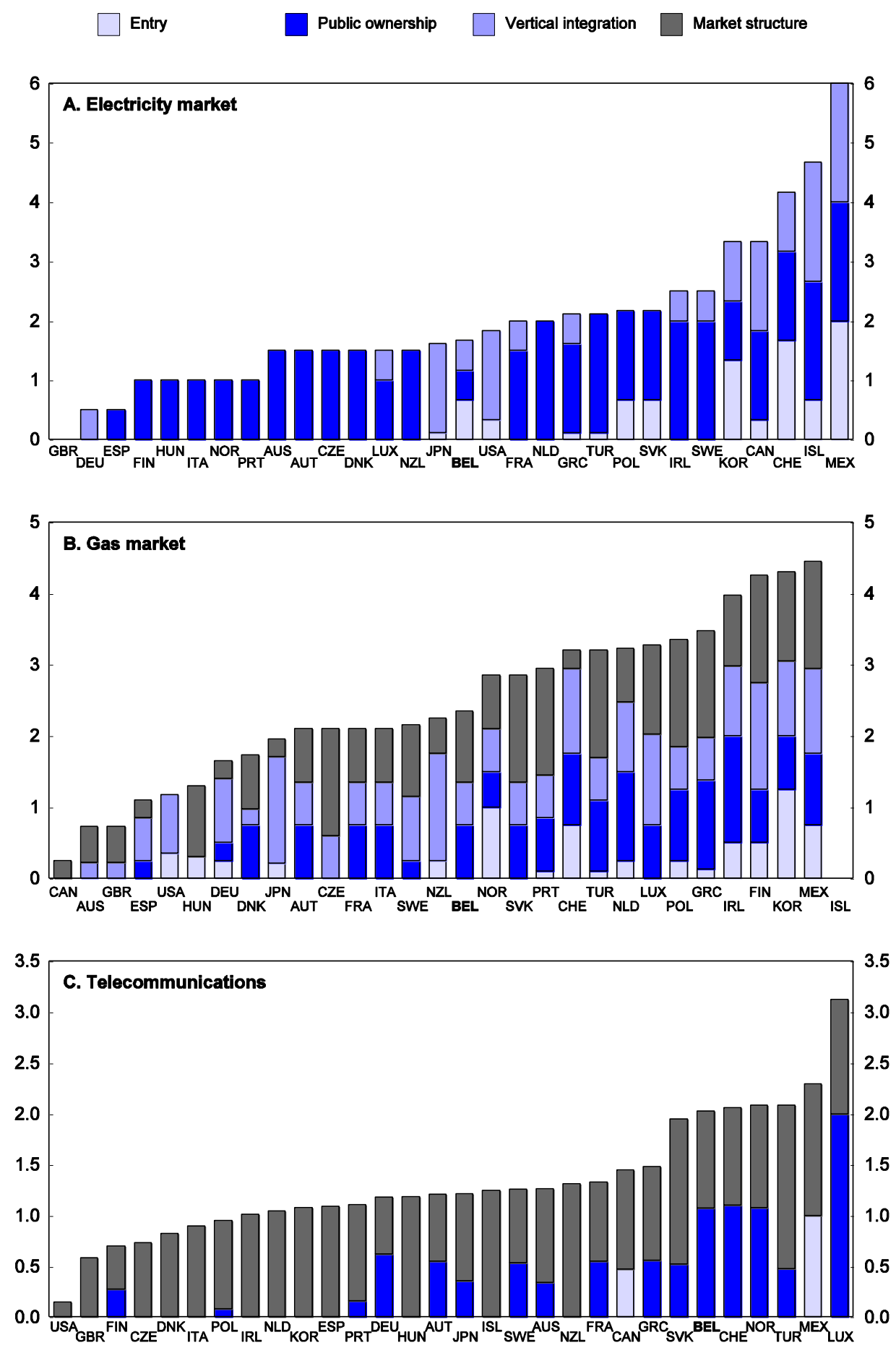

Source: OECD (2009), PMR database. 


\section{Box 6. The Gaz de France - Suez merger and concentration on the Belgian energy market}

The merger between Gaz de France (GDF) and Suez was announced in February 2006 and due to its large-scale characteristics was subject to the EU regulation regarding limits on concentration. The Commission authorised the deal in November 2006, amid concerns regarding the large role of the new company in specific markets. Before the deal, the two companies had strong positions in the Belgian energy markets, thus the merger posed problems of further increasing the concentration of the already highly concentrated energy sector. In order to receive the approval of the merger by the European Commission the companies made a number of commitments regarding the Belgian markets (Table 4).

\section{Table 4. The Belgian energy market and GDF-Suez}

Concentration before and after the merger

\begin{tabular}{lcc}
\hline $\begin{array}{l}\text { Segment of } \\
\text { the market }\end{array}$ & $\begin{array}{c}\text { Role of GDF and Suez } \\
\text { before the merger }\end{array}$ & $\begin{array}{c}\text { Commitments of GDF and Suez } \\
\text { in light of the merger }\end{array}$ \\
\hline
\end{tabular}

Production, imports and wholesale

Transmission

Distribution

Supply
Electricity: $85 \%$ of electricity production was in the hands of Suez-owned Electrabel, while another $8 \%$ was in the hands of SPE (partly owned by GDF).

Gas: Suez-owned Distrigas controlled over $85 \%$ of the wholesale market (including control of the main international hub and LNG terminal in Zeebrugge) while GDF held another $10.4 \%$.

Electricity: Suez had the blocking minority in the electricity transmission system operator (Elia) while SPE also held a small share.

Gas: Suez held over $57 \%$ of shares in Fluxys (the transmission system operator).

Electricity: Electrabel (owned by Suez) had shares in roughly $80 \%$ of the distribution system operators, within the regional restrictions limiting private sector participation to minority shares.

Gas: Suez had stakes in $80 \%$ of the distributors.

GDF and Suez jointly controlled over $70 \%$ of the electricity supply market and about $80 \%$ of the gas supply market.
Full spin-off of SPE (remaining share was sold to Centrica in January 2009).

Sale of Suez's holding in Distrigas (with some restrictions, was sold to ENI in May 2008). Creation of Fluxys International with a maximum $60 \%$ ownership of the GDF-Suez from part of Fluxys (the transmission system operator) in order for the group to retain control of the Zeebrugge import hub and LNG terminal.

GDF-Suez reduced its stake in Elia to below a blocking minority of $25 \%$, in accordance with a previous commitment (December 2007).

Reduction of the group's stake in Fluxys (was reduced to just below 39\% in September 2008 in a transaction with the municipal holding Publigaz).

Sale of Suez's holding in Distrigas (with some restrictions, was sold to ENI in May 2008).

Source: International Network of Energy Regulators and European Commission. 


\section{The performance of the telecommunication sector over the past decade has been disappointing}

15. Productivity growth in the telecommunication sector was well below that in most other OECD countries (Table 1) and consumers were often forced to pay higher prices than in neighbouring countries and the introduction of new technologies was lagging. Although explicit barriers to entry do not seem to be a problem in most segments of the market (Figure 6, Panel C), one of the most visible issues is the high concentration of the sector.

\section{Fixed telephony}

16. Following the liberalisation of telecommunications on $1^{\text {st }}$ January 1998, new entrants have not been able to gain a strong position in some of the key segments of the market, which remained concentrated in the hands of the majority state-owned incumbent Belgacom. Belgian broadband offers remain on the expensive side in comparison to other OECD countries (Figure 7). Moreover, a particular feature of the Belgian broadband is that practically all offers have monthly download quotas (bit-caps) which tend to be lower than in other countries. This further raises the price of internet usage as exceeding the quota entails an additional cost. ${ }^{8}$ Furthermore, the Belgian consumer does not have access to top technology (e.g. fibre-to-the-home) and the advertised speeds remain well below the fastest offers in leading OECD countries (Figure 8). As a result, broadband penetration, among the highest in the OECD in 2002, has since been growing slowly and is lower than in many countries (though still above average). Finally, the Belgian consumer pays an excessive price for triple-play offers (broadband, TV and telephone) while the offers are of inferior quality (Table 5 shows a comparison with France, where the regulator has been particularly active in the telecom market).

17. Broadband is provided mainly through DSL lines and to a smaller, but still internationally high, extent via cable. Local loop unbundling (LLU) of cable networks is technically infeasible and due to the high concentration in the cable sector, this technology has failed to put sufficient competitive pressure on the incumbent's DSL offer. In DSL itself, the main alternatives to the incumbent's offer are provided via bitstream (renting capacity from the incumbent and reselling it) which is incapable of challenging the incumbent's position as it does not allow for sufficient differentiation of products (e.g. providing television over internet). Overall, the level of local loop unbundling of DSL lines is very low when compared with OECD countries with a liberalised market, despite a comparable regulated price of provision. ${ }^{9}$ Until 2007 this was largely a consequence of high (regulated) prices of unbundling, which have since been lowered to internationally low levels (EC, 2008a). Nevertheless the latter development has failed to benefit the final consumer. Part of the explanation is historical and the effects of lower tariffs should eventually be felt. However, many costs related to unbundling remain high (e.g. collocation, installation and de-installation) increasing the cost of entry. Secondly, for a number of years, the incumbent has failed to comply with

8. Caps generally prevail in countries where geography limits the connection to the rest of the world (e.g. located on islands) and in principle Belgium's location does not explain the prevalence of caps. In 2008 only four OECD countries had $100 \%$ of offers with caps (Australia, New Zealand, Canada and Belgium) while Iceland and Ireland had a domination of offers with caps (OECD broadband portal). The average level of caps in Belgium was the second lowest in the OECD, of a range comparable with only New Zealand (on average 20GB in 2008, but being as low as $250 \mathrm{MB}$ in the low-end offers). Belgian bit-caps are reached relatively fast, compared to the advertised maximum download speed and may impose a higher de facto charge for high users. In mid-2008 one challenging provider started offering uncapped downloads, but has since been followed by only one competitor (in December 2008).

9. By January 2008, out of over 1.6 million DSL lines, less than 40000 , that is $2.5 \%$ of the total, were fully unbundled. In contrast, $18 \%$ of lines are unbundled on average in the EU 27, 31\% in Germany, 23\% in France and $10 \%$ in the Netherlands. Shared access lines constitute slightly above $1 \%$ of total lines in Belgium. 
requirements concerning the timing and quality of provisioning and servicing of lines, and the regulator has failed to enforce these obligations. ${ }^{10}$ Furthermore, the incumbent has appealed against almost all of BIPT's decisions and cases get held up in the Court of Appeal or in some cases at the Competition Council for a relatively long time given the dynamic nature of the sector. In the end BIPT's decisions were often annulled on formal grounds, increasing uncertainty for new entrance (Platform, 2007). Such developments create an implicit barrier for new entrants, who face high uncertainty regarding the quality of services provided by the incumbent, and therefore potential problems with assuring a high quality of the end product.

Table 5. Triple-play is significantly more expensive than in France

\begin{tabular}{|c|c|c|c|c|c|}
\hline Company & $\begin{array}{c}\text { Internet connection } \\
\text { speed (download, } \\
\text { Mbps) }\end{array}$ & $\begin{array}{c}\text { Bitcap } \\
\text { (GB) }\end{array}$ & $\begin{array}{c}\text { Television } \\
\text { channels }\end{array}$ & $\begin{array}{l}\text { Telephone (unlimited free calls } \\
\text { included) }\end{array}$ & $\begin{array}{c}\text { Price } \\
(€)\end{array}$ \\
\hline \multicolumn{6}{|l|}{ France } \\
\hline Free & 28 & $\ldots$ & $50+$ & 70 countries & 29.99 \\
\hline Neuf & 20 & $\ldots$ & $50+$ & $60+$ countries & 29.99 \\
\hline Orange & 18 & $\ldots$ & $50+$ & national only & 39.99 \\
\hline Numericable & 100 & $\ldots$ & $50+$ & 45 countries & 31.90 \\
\hline \multicolumn{6}{|l|}{ Belgium } \\
\hline Belgacom & 1 & 1 & $50+$ & off peak only ( 1 country) ${ }^{1}$ & 47.00 \\
\hline Belgacom & 4 & 4 & $50+$ & off peak only ( 1 country) ${ }^{1}$ & 57.00 \\
\hline Belgacom & 12 & 25 & $50+$ & off peak only ( 1 country) ${ }^{1}$ & 67.00 \\
\hline Telenet & 4 & 5 & $50+$ & off peak only (36 countries) & 40.00 \\
\hline Telenet & 12 & 30 & $50+$ & off peak only (36 countries) & 50.00 \\
\hline Telenet & 20 & 30 & $50+$ & off peak only ( 36 countries) & 60.00 \\
\hline Telenet & 25 & 100 & $50+$ & off peak only (36 countries) & 70.00 \\
\hline Numéricable & 100 & 100 & $50+$ & 42 countries $^{2}$ & 59.99 \\
\hline
\end{tabular}

1. Fixed EUR 5 activation fee for international calls.

2. Very limited promotional offer.

Source: Company websites, December 2008.

10. The regulator generally has refrained from fining Belgacom. As regards local loop unbundling, by July 2006 BIPT registered numerous complaints from the alternative operators about Belgacom not meeting legal deadlines for line installation and service works. Instead of adopting a tough stance on the violations BIPT effectively doubled legal time limits for Belgacom. This decision had an adverse impact on consumer welfare instead of forcing the incumbent to devote additional resources to LLU and servicing. The penalties for exceeding the maximum timeline were revised, detaching them from the monthly rental fee, however they have been capped at relatively low levels. Since then the timing schedules are to be reduced gradually, however despite recent improvements, Belgacom still seems to have problems fulfilling them, but uses inevitable deviations from the forecasts on LLU which the competitors are obliged to provide in order to avoid fines. Similarly, Belgacom's competitors give details on the problems BIPT has experienced in forcing Belgacom to include ADSL2+ in to its reference offer for bit stream (despite persistent refusal to fulfil BIPT's request no fine was issued). Only recently (July 2008) a EUR 3 million was issued for failing to comply with BIPT's decision on mobile phone charges. 
Figure 7. Broadband internet is relatively expensive ${ }^{1}$

Price per unit of maximum download speed ${ }^{2}$ (USD)

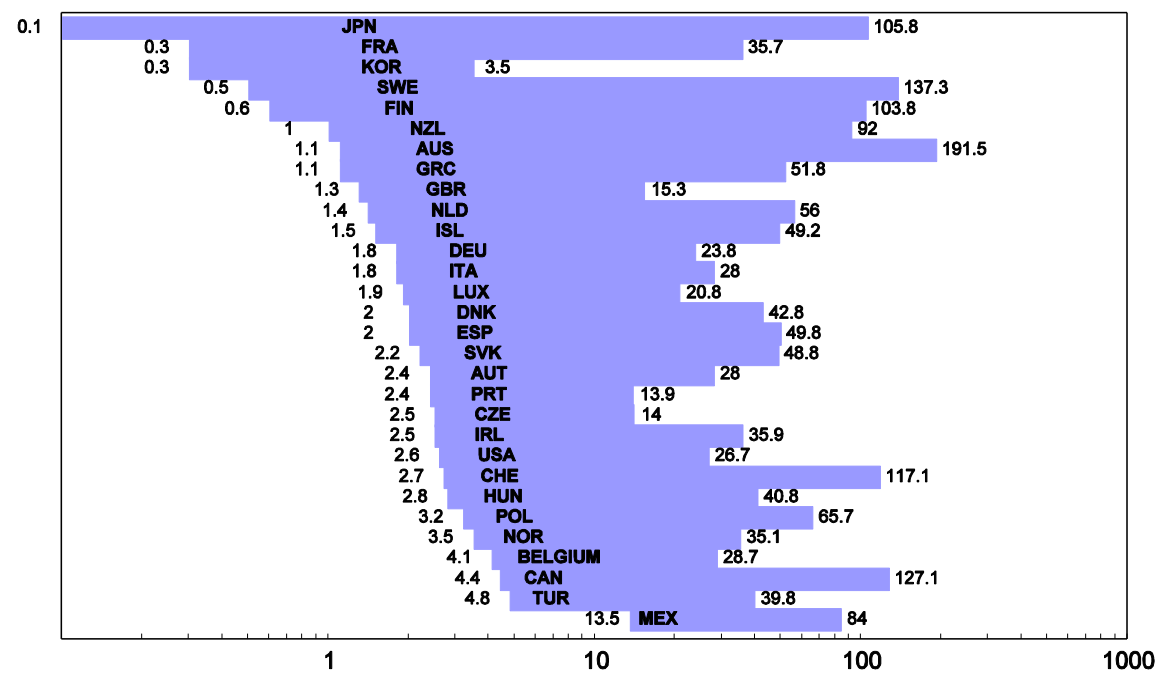

1. October 2008, logarithmic price scale.

2. USD per $1 \mathrm{Mbps}$ of maximum advertised download speed.

Source: OECD (2009), Communications Outlook.

Figure 8. Advertised download speeds are relatively low

September 2008

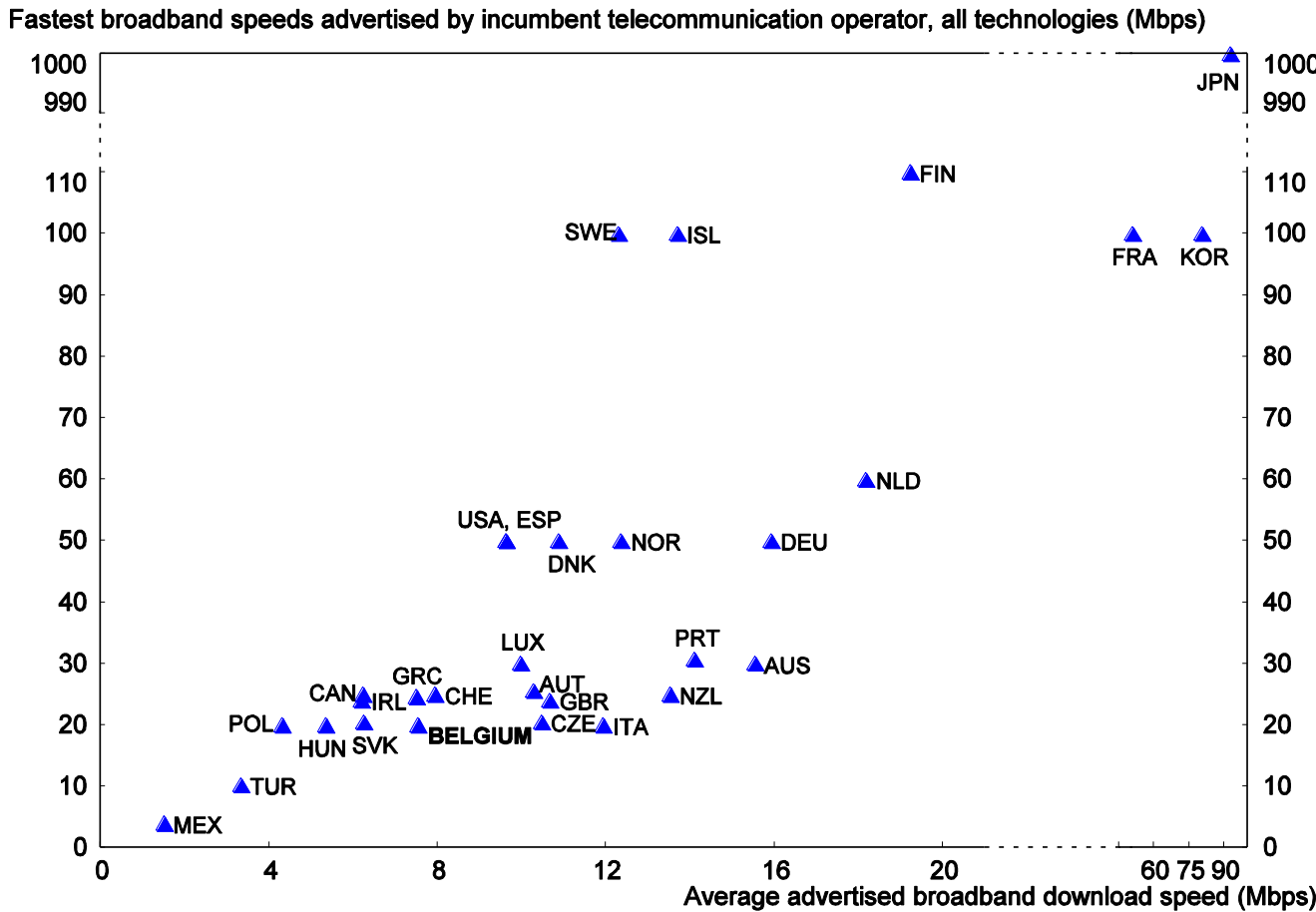

Source: OECD (2009), Communications Outlook. 
18. The regulatory and legal framework was earlier criticised for lacking a consistent and systematic approach and giving the impression of improvisation (Dehousse and Zgajewski, 2003). The regulator's powers still seem somewhat weaker when compared with the OECD best practice. Firstly, what is rather unusual, dispute settlement is outside its competencies and is carried out by the Competition Council. Second, the regulator appears to have fewer tools available to enforce its decisions than for example regulators in Finland, Sweden and Spain (ECTA, 2008). BIPT is unable to impose periodic penalties to ensure compliance, to suspend an introduction of an offer until the ex ante obligations are fulfilled and is tied up by a strict confidentiality law. ${ }^{11}$ Moreover, although BIPT's independence was improved in 2003, there are indications it may still need strengthening in particular given the controlling share of the state in the incumbent (Box 4). As a consequence, Belgacom is a significant contributor to the federal budget, which leads to a potential conflict of interest: the state is a regulator in charge of promoting competition and the state benefits from the incumbent's profits. Therefore, the privatisation of Belgacom would further clarify the incentives to empower the sectoral regulator. In the past years, a number of sources have accused the regulator of being under political influence (Platform, 2007, ECTA, 2008, Test-Achats, 2007, 2008) and of neglecting the enforcement of local loop unbundling (Platform, 2007). Each of these issues should be reviewed and addressed, so that the regulator can take an active part in promoting competition on the telecom market in order to bring telecommunication productivity growth more in line with other OECD countries and to allow consumers to benefit from lower prices and better offers. This should be done primarily through a tough stance on the incumbent's violations, including a determined use of fines in order to lower implicit entry costs and encourage LLU. Furthermore, any pressures to dilute the regulatory powers, for example due to the overlaps of competencies with the Community-level broadcast content regulators, should be strongly resisted. Notably, the government is preparing a reform which should improve the powers of the regulator (Box 4).

19. Another important issue is the imposition of social tariffs on all the operators in fixed line telephony and their funding (Box 5). The implementation of the social tariffs has raised numerous problems, including the problems of competitors' access to the database which would allow the verification of eligibility (Platform, 2007) which now seems to have been solved. Moreover the compensation mechanism seems not to be in line with the EU's Universal Service Directive as there are no legal instruments to establish whether provision of social tariffs constitutes an unfair burden. Due to the larger share of those benefiting from social tariffs among Belgacom's clients, the fund risks being an effective subsidy to the incumbent. If the government is determined to pursue the social tariff element of universal service, it should consider periodically auctioning off the service in a competitive bid, or at the least obliging the regulator to conduct investigations whether this service constitutes an unfair burden, equipping it with the necessary legal tools. Last but not least, there could be concerns for the future development of competition in the market if Belgacom upgrades its network using VDSL, since this technology increases the cost of unbundling for new entrants. Therefore the regulator needs to examine how to ensure competition with this technology (steps in this direction would include assuring access to passive infrastructure and backhaul facilities). It is also desirable to encourage the development of fibre-to-the-home (FTTH) technology.

\section{Mobile telephony}

20. Mobile call charges in Belgium tend to be on the expensive side: low-usage charges appear close to the OECD average, despite an internationally high number of virtual operators (MVNO's) and resellers targeting this market, while high-usage prices are among the most expensive (Figure 9). Mobile phone penetration is among the lowest in the EU, showing little signs of catching up. The market is divided

11. For example, the decision whether data passed on to BIPT is confidential or not is left to its author. No motivation must be given, and the regulator cannot challenge this decision, thus the use of obtained data may be limited. 
between three network operators, including the dominant player Proximus, which is owned by the fixed telephony incumbent, Belgacom. ${ }^{12}$ The numerous resellers and MVNO's (above 25), contrary to other countries, have failed to gain a significant market share and to bring down the price of mobile calls (the combined market share remained below $1 \%$ by 2008, EC, 2008a). Mobile termination charges, despite being lowered in 2008, remain well above those in competitive markets like the United Kingdom, Sweden and Finland. Moreover, in 2008 the College of Competition Prosecutors has found evidence of the abuse of dominant position by Belgacom Mobile (in the period 2002-2005) and the case is currently pending before the Council (the complaint was filed in 2005). The incumbent's appeals against the lowering of termination charges lead to lengthy legal procedures in the Court of Appeal and significantly increase uncertainty for resellers.

Figure 9. Prices for mobile phone calls tend to be high

Total price in USD, February 2008

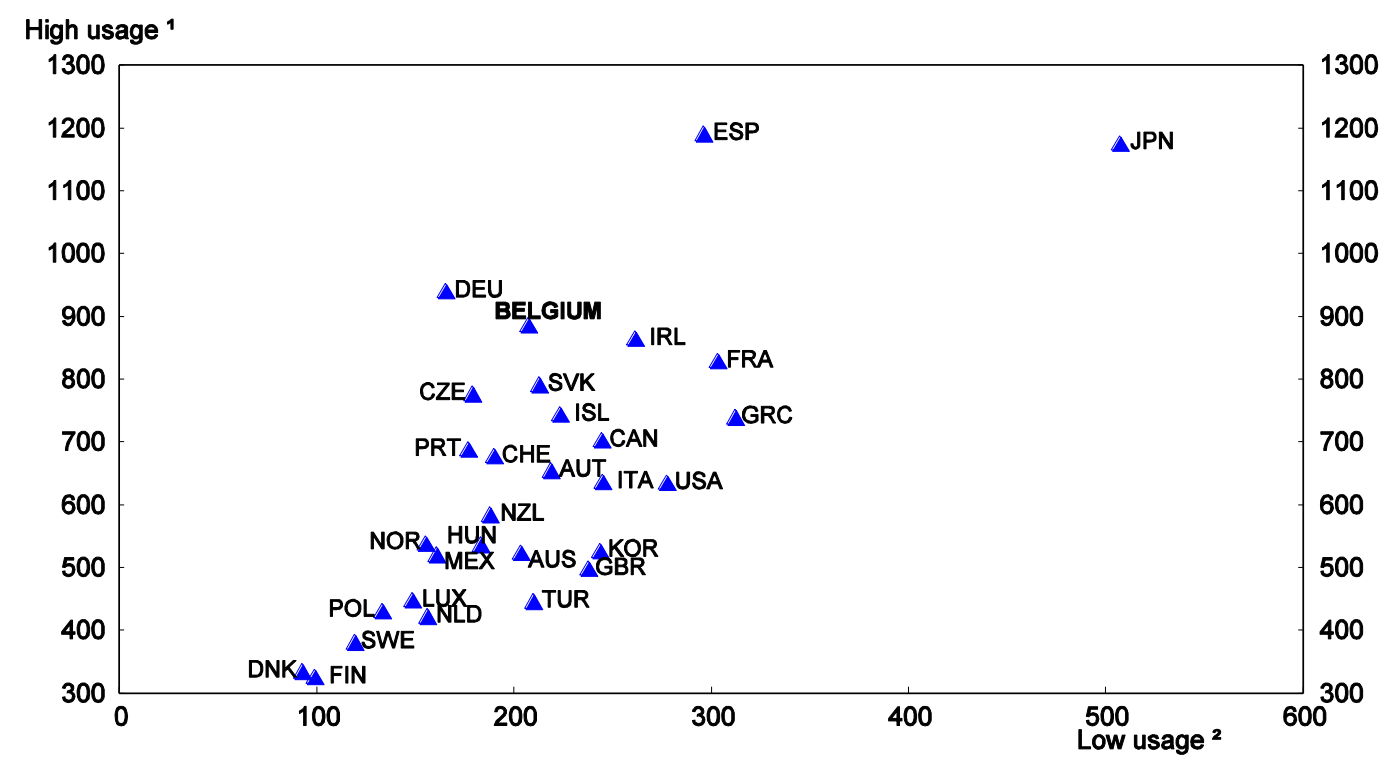

1. The OECD basket of mobile telephone charges (high usage) includes subscription and usage (1680 minutes of voice calls, 660 SMS messages and 12 MMS, distributed between peak and off-peak hours and based on an average call duration) over a oneyear period. Calling patterns were all determined through extensive discussions with carriers across the OECD.

2. The OECD basket of mobile telephone charges (low usage) includes subscription and usage ((360 minutes of voice calls, 396 SMS messages and 8 MMS.

Source: OECD, Communications Outlook database.

21. The regulator should focus on lowering mobile termination rates to meet the levels in the most competitive markets. In order to assure that the business models of the resellers are not undermined by uncertainty related to the incumbent challenging the regulator's decisions, the court cases should be speeded up in order to assure that they better match the dynamic nature of the sector. This should be achieved through appointing the Competition Council as the institution of appeal against all decision of the regulator, which may possibly require increasing the Council's resources. In order for the reduction of

12. The three market players are Proximus (owned by Belgian fixed-line incumbent Belgacom) with $45-49 \%$ of the market according to different estimates, Mobistar (owned by the French incumbent France Telecom) with $31-34 \%$ of the market and BASE (owned by the Dutch incumbent KPN) with the remaining share of around $20 \%$. 
mobile termination rates to benefit the final consumer, sufficient competitive pressure on retail and wholesale prices must be assured. A desirable step in this direction, already under consideration by the government is the introduction of the fourth network license. To facilitate the expansion of resellers and the potential new operator, the long length of service contracts should be reduced by limiting their maximum duration. The process for number portability should be streamlined to reduce the time taken to port a number. As for the social tariffs, the benefits of the extension to mobile phones are disputable (EC, 2006). As in fixed telephony, if the government considers social tariffs desirable, it should consider periodically auctioning off the service in a competitive bid and pay for it directly from the budget.

\section{Liberalisation in postal services and rail transport in lagging}

22. The liberalisation of both the rail transport and postal services market is proceeding slowly, in line with the requirements of the European Commission. The latter stipulates the eventual full opening of both markets to competition: rail transport by January 2010 and postal services by January 2011. In the postal services sector, while competition seems to be well in place in the courier services, it is practically non-existent in the addressed letter segment (van der Lijn et al., 2008). As a consequence, despite the favourable characteristics of a relatively evenly spread, dense population, Belgian consumers suffer from higher prices, in particular for letters, and from a poorer quality of services that in most neighbour countries (Deutsche Post, 2008 and EC, 2008b). The sectoral regulator has, according to some sources, been perceived as inactive in the field of postal services (Baeke, 2008). Indeed the quality criteria agreed with the State have not been met by the incumbent, but no sanctions were issued. Although the situation is expected to improve as new sorting centres have been put in place, sanctions for the violation of preset quality standards should be significant and automatic, leading to stronger incentives to improve the quality of services. Moreover, new entry may be deterred by a number of additional Belgium-specific regulations. These include a VAT exemption on certain services provided by the incumbent and a particularly broad range of universal service obligations (Box 5). The former distorts the market, biasing the incumbent towards servicing the residential market and the competitors towards the business market while the broadness of USO's leads to a high cost of provision. ${ }^{13}$ This may result in the subsidisation of the incumbent who, even in a fully liberalised market, will remain the only player with sufficient infrastructure to provide the broad USO's. Thus it would be desirable that each of the services currently included in the USO bundle, if deemed indispensable by the government, to be separately auctioned off according to best offer. Until then, the pricing should fully take into account the benefits of brand display.

23. As concerns rail transport, virtually no steps have been taken towards opening the passenger transport market to competition. The freight market is legally open for international connections since January 2006 and one year later for national connections, but remains strongly dominated by the state-owned incumbent. The publicly owned incumbent consists of the monopolist passenger transport service provider, the dominant freight service provider and the infrastructure operator. The passenger and freight segments have separate accounts while the infrastructure operator is required to be legally separated from the service providers. However, this separation is incomplete due to overlaps in terms of high level personnel. The sectoral regulator, which remains an agency within the Ministry of Transport, is in need of strengthening and more independence in order to assure non-discriminatory third party access to tracks, slots and marshalling facilities. Moreover at the moment, passenger connections are negotiated between the infrastructure operator, the monopoly service provider and the state which has a monopsonistic position.

13. The lack of VAT on postal services provided by La Poste in the area subject to USO gives an advantage to the incumbent towards customers unable to reclaim their VAT (mainly households) and a disadvantage towards other customers. Households, pay the nominal price on which the incumbent does not pay VAT. Business customers also pay the nominal price but they can reclaim the VAT from the competitors' price while not from the incumbent's price. Moreover, as the incumbent uses inputs subject to VAT, it cannot reclaim the tax when offering a service not subject to value added taxation. 
Once the market is liberalised lower levels of governments should be empowered to purchase desired services (as for example in Germany) to introduce a more market-based provision of services. Strengthening the regulator, finalising the legal separation and changes in the service acquisition framework are recommended along with the swift full opening up to competition. Finally, successful introduction of competition in the rail sector would also be facilitated by a uniform, market-oriented approach to universal service across the network sectors in order to guarantee a level playing field and to avoid entry barriers to new competitors.

\section{Conclusion}

24. Recent reforms of competition policy enforcement and the favourable stance of the government towards more competition constitute undeniable progress towards more competitive domestic markets. However, this may not suffice to bring productivity in certain sectors, such as retail distribution, telecommunication and energy, in line with that of the leading OECD countries. In order to reap the full benefits of liberalisation in terms of higher productivity and employment growth as well as competitive prices, further steps need to be taken. Overall, the system of regulation as a whole may need reconsideration in order to be aimed at a clearly defined, efficient role of each regulatory authority and at securing effective cooperation between the authorities. A number of additional policy measures which should be taken in order to assure that Belgian consumers benefit from competition on the market are summarised in Box 7 below.

\section{Box 7. Policy recommendations to enhance competition}

\section{The Competition Authority needs further strengthening}

- The effective independence and the accountability of the Competition Authority should be monitored, in order to assess whether further strengthening in these areas is necessary. Resources may need to be reviewed and eventually increased to levels observed in other small economies with a proactive competition enforcement stance.

- In order to avoid foregoing or postponing important cases and to allow the Competition Authority to adopt a more proactive role in analysing the market, its resources should be increased. The Competition Council should be established as the institution of appeal against all the decisions of the sectoral regulators.

- In order to improve deterrence, the law should provide for criminal sanctions for hard-core cartel infringements. High fines should not be avoided as they deter anticompetitive practices and increase the attractiveness of applying for leniency. Confidentiality rules should be reviewed and possibly loosened with a goal of facilitating the cooperation of the Authority with network sector regulators.

\section{Competition-burdening regulation in retail distribution should be abolished}

- In order to benefit from the competitive nature of the retail sector, with the goal of creating employment, improving purchasing power and bringing productivity in line with other OECD countries, the competition inhibiting regulation should be scrapped (e.g. restrictions on sales below cost, opening hours and tied sales, black-out periods). Zoning laws for large outlets should be restricted to evaluating spatial effects (urban planning, access, safety) in order to assure they do not protect existing retailers against new competition.

\section{Sectoral regulation needs to focus on implicit barriers to new entry}

- To improve the effectiveness of regulatory action in the energy sectors, the complicated regulatory structure should be reconsidered. Reforming the setup to establish a single, independent nationwide regulator with competencies including the areas of distribution and supply of gas and electricity in order to deal with the local monopolies, should reduce the bureaucratic procedures and the burdens for new entrants. Alternatively the binding co-operation procedures between the regulatory bodies should be introduced in order to align the objectives of regional regulators, increase the efficiency of communication procedures. Independence of the regional regulators from the governments should be assured. 
- In order to facilitate new entry, ownership separation between different segments of the electricity and gas markets should be considered. For the same reason, regulatory efforts should be strengthen to ensure that the ban on cross-subsidisation between electricity and gas markets is enforced.

- New entry should be promoted by improving the role of the wholesale exchange and reconsidering the universal service obligations (USOs) and their variation across regions. If sub-federal governments wish to implement additional social policies they should finance it from their own budget rather than through distribution tariffs.

- In the electricity sector further efforts should be made to increase interconnection capacity, encourage new entry and continue auctioning off of the incumbent's production capacity.

- An anonymous wholesale pool for gas should be developed in order to facilitate new entry. Assuring strong vertical separation, between the Zeebrugge gas hub and the LNG terminal on the one hand, and the dominant players in the energy market on the other is strongly advised in order to assure third party access. The effectiveness of recent measures to reduce long contract lengths in the gas wholesale market should be evaluated and if necessary new measures should be adopted.

The telecommunication regulator needs to toughen its stance against incumbent's violations

- The regulator should be given the ability to introduce periodic penalties and to block the introduction of offers if ex ante conditions are not fulfilled. Furthermore, the regulators independence may need explicit strengthening while the government should proceed with the privatization of the incumbent.

- In fixed telephony the regulator should increase efforts to encourage local loop unbundling (LLU) through strengthening its stance on the incumbents violations in the areas of deadlines for LLU provision, service level agreements, collocation and the quality of services provided. Fines for the incumbent's violations should be used more widely and preferably be automatic. The regulator should strongly promote competition in new generation networks.

- In order to avoid inefficient complication of the regulatory structure and the dilution of powers, any pressure from Community-level broadcasting regulators to gain power to regulate transmission infrastructure should be strongly opposed.

- In mobile telephony the regulator should increase efforts to lower the mobile termination charges and to decrease the uncertainty surrounding its decisions through a better preparation to defend them in court.

- $\quad$ The fourth network operator should be introduced as soon as possible. Maximum contract duration should be reduced in order to increase flexibility and facilitate entry. USOs should be funded from the government budget via competitive tendering.

\section{Faster opening up of the other network sectors is essential}

- Competition should be introduced in all segments of postal services. Efforts to decrease entry barriers should be increased: the scope of USOs should be reconsidered and the clause on additional fund for USO financing should be eliminated. Again USO's (each service individually) should be financed directly from the budget through competitive tenders.

- Faster opening up of the rail transport sector should be accompanied with strengthening the independence and powers of the regulator. 


\section{Bibliography}

Accord du Gouvernement (2008), Belgian Government website, www.premier.be

Bassanini, A., and R. Duval (2006), "Employment Patterns in OECD Countries: Reassessing the Role of Policies and Institutions", OECD Economics Department Working Paper, No. 486, OECD, Paris.

Baeke, A. (2008), “Postal Liberalisation in Belgium”, Free and Fair Post Newsletter, 2008 Q3.

Bertrand, M. and F. Kramarz (2002), "Does Entry Regulation Hinder Job Creation? Evidence from the French Retail Industry", The Quarterly Journal of Economics, vol. 117(4), pp. 1369-1413.

Biatour, B. and C. Kegels (2008), "Growth and Productivity in Belgium", Federal Planning Bureau, Working Papers, 0817, Belgium.

Boylaud, O. and G. Nicoletti (2001), "Regulatory Reform in Retail Distribution", OECD Economic Studies, No. 32, vol. 1, pp. 253-274, OECD, Paris.

CPB (Centraal Planbureau) (1995), "Economische Effecten van Liberalisering van Winkeltijden in Nederland", Centraal Planbureau Working Paper, No. 74, Den Haag, February 1995.

Conway, P., V. Janod and G. Nicoletti (2005), "Product Market Regulation in OECD Countries: 1998 to 2003", OECD Economics Department Working Papers, No. 419, OECD, Paris.

Conway, P. and G. Nicoletti (2006), "Product Market Regulation in the Non-Manufacturing Sectors of OECD Countries: Measurement and Highlights", OECD Economics Department Working Papers, No. 530, OECD, Paris.

Conway, P., D. de Rosa, G. Nicoletti and F. Steiner (2006), "Product Market Regulation and Productivity Convergence", OECD Economic Studies, No. 43, OECD, Paris.

Creusen, H., B. Vroomen, H. van der Wiel, and F. Kuypers (2006), "Dutch Retail Trade on the Rise? Relation between competition, innovation and productivity", Central Planning Bureau Working Paper, No. 137.

Deutsche Post (2008), Letter Prices in Europe - Up-to-date International Letter Price Survey, $7^{\text {th }}$ Edition, March 2008.

Dehousse. F. and T. Zgajewski (2003) "Les Nouveaux Développements de la Réglementation des Télécommunications en Belgique (1999-2003) ”, J.T., vol. 122, issue 6099, pp. 425-433

EC (European Commission) (2006), Impact Assessment Report, Annex to the Report Regarding the Outcome of the Review of the Scope of Universal Service in Accordance with Article 15(2) of Directive 2002/22/EC, Commission Staff Working Document SEC(2006) 445. 
EC (2007a), Prospects for the Internal Gas and Electricity Market: Implementation Report, SEC(2006) 1709, Commission Staff Working Document accompanying document to the Communication from the Commission to the Council and the European Parliament,.

EC (2007b), "Antitrust: Commission Increases Competition in the Belgian Gas Market - Frequently Asked Questions", European Commission Press Release MEMO/07/407, Brussels, $11^{\text {th }}$ October 2007.

EC (2008a), Progress Report on the Single European Electronic Communications Market 2007 (1 $3^{\text {th }}$ Report), SEC(2008) 356, Commission Staff Working Document accompanying document to the Communication from the Commission to the European Parliament, the Council, the European Economic and Social Committee and the Committee of the Regions.

EC (2008b), Report from the Commission to the Council and the European Parliament on the Application of the Postal Directive, (Directive 97/67/EC as amended by Directive 2002/39/EC.)

ECTA (European Competititve Telecommunications Association) (2008), Report on the Relative Effectiveness of Framework for Electronic Communication in Austria, Belgium, Czech Republic, Denmark, Finland, France, Germany, Greece, Hungary, Ireland, Italy, the Netherlands, Norway, Poland, Portugal, Slovenia, Spain, Sweden, the United Kingdom and Turkey, ECTA Regulatory Scoreboard, 2008.

Haffner, C. and P. Van Bergeijk (1997), « Regulatory Reform in the Netherlands - Macroeconomic Conséquences and Industry Effects » Directie Martwerking, Ministerie va Economische Zaken, October.

Høj, J., T. Kato and D. Pilat (1995), "Deregulation and Privatisation in the Service Sector", OECD Economic Studies, No. 25, Vol. 2, pp. 37-74, OECD, Paris.

Høj, J. (2007), "Competition Law and Policy Indicators for the OECD countries", OECD Economics Department Working Papers, No. 568.

IEA (International Energy Agency) (2006), Energy Policies of IEA Countries, Belgium 2005 Review.

Inklaar, R and M. Timmer (2008), "GDDC Productivity Level Database: International Comparisons of Output, Input and Productivity at the Industry Level”, Groningen Growth and Development Centre, University of Groningen, the Netherlands.

van der Lijn. N., P. de Bas, G. Carter, F. van Doorn, N. van Gorp, H. Kok, J. Mathijssen, L. Meindert, and P. Vis (2008), Main Developments in the Postal Sector (2006-2008) Final report, Report prepared for the European Commission, DG Internal Market and Services, ECORYS Nederland.

Lisbon Strategy (2008), National Reform Programme 2008-2010, Belgium, October 2008.

NBB (National Bank of Belgium) (2008), "The Trend in Inflation in Belgium: an Analysis by the NBB at the Request of the Federal Government", National Bank of Belgium, Economic review, April Special Edition.

Nicoletti. G., S. Scarpetta and O. Boylaud (2000), "Summary Indicators of Product Market Regulation with and Extension to Employment Protection Legislation", OECD Economics Department Working Papers, No. 226, OECD, Paris. 
Nicoletti. G and S. Scarpetta (2003), "Regulation, Productivity, and Growth: OECD Evidence," Policy Research Working Paper, Series 2944, The World Bank.

OECD (2008), "Land Use Restrictions as Barriers to Entry", OECD Directorate for Financial and Enterprise Affairs Competition Committee WP2 Paper, OECD, Paris.

OECD (2009), Economic Survey of Belgium, 2009, OECD, Paris.

Pilat. D. (1997), "Regulation and Performance in the Distribution Sector", OECD Economics Department Working Papers, No. 180, OECD, Paris.

Platform (2007), Contribution to the $13^{\text {th }}$ Implementation Report, Brussels, Belgium, $11^{\text {th }}$ October 2007.

SPF Economie (2008), Evaluation et Modernisatrion du Droit Economique, Ministry of Economics.

Test-Achat (2007), "La Belgique en Perte de Vitesse, Comparatif International des Tarifs Internet", Test-Achats, No. 510, July 2007.

Test-Achat (2008), "La Belgique, Cancre du Web, Tarifs Internet : Comparaison Internationale", Test-Achats, No. 521, June 2008.

Wölfl, A., I. Wanner, T. Koźluk and G. Nicoletti (2009), "Ten Years of Product Market Reform in OECD Countries - Insights from a Revised PMR Indicator”, OECD Economics Department Working Paper, No. 695, OECD, Paris. 


\section{WORKING PAPERS}

The full series of Economics Department Working Papers can be consulted at www.oecd.org/eco/working_papers/

735. Prudential regulation and competition in financial markets

(December 2009) Rüdiger Ahrend, Jens Arnold and Fabrice Murtin

734. Keeping Slovenian Public Finances on a Sustainable Path

(October 2009) Pierre Beynet and Willi Leibfritz

733. Pedal to the metal: Structural reforms to boost long-term growth in Mexico and spur recovery from the crisis

(October 2009) David Haugh and Agustin Redonda

732. Achieving higher performance: Enhancing spending efficiency in health and education in Mexico (October 2009) Cyrille Schwellnus

731. Russia's long and winding road to a more efficient and resilient banking sector (October 2009) Geoff Barnard

730. How do institutions affect structural unemployment in times of crises?

(October 2009) Davide Furceri and Annabelle Mourougane

729. Understanding the world trade collapse

(October 2009) Calista Cheung and Stéphanie Guichard

728. Estonia and euro adoption: Small country challenges of joining EMU

(October 2009) Zuzana Brixiova, Margaret H. Morgan and Andreas Wörgötter

727 Towards better schools and more equal opportunities for learning in Italy (June 2009) Romina Boarini

726. Iceland: Challenging Times for Monetary and Fiscal Policies (August 2009) Andrea De Michelis

725. Iceland: The Financial and Economic Crisis (August 2009) David Carey

724. The role of transparency in the conduct of monetary policy (September 2009) Makoto Minegishi and Boris Cournède

723. Raising education outcomes in Greece (September 2009) Vassiliki Koutsogeorgopoulou

722. Improving the performance of the public health care system in Greece (September 2009) Charalampos Economou and Claude Giorno

721. Is there a case for price-level targeting?

(August 2009) Boris Cournède and Diego Moccero 
720. The challenge of restoring French competitiveness (August 2009) Rafal Kierzenkowski

719. Improving the functioning of the Slovenian labour market (August 2009) Isabell Koske

718. What drives sovereign risk premiums? An analysis of recent evidence from the Euro Area (July 2009) David Haugh, Patrice Ollivaud, and David Turner

717. The English National Health Service: an economic health check (July 2009) Peter Smith and Maria Goddard

716. Financial stability in the United Kingdom: Banking on prudence (July 2009) Philip Davis

715. Economic growth and the role of taxation- disaggregate data (July 2009) Gareth D. Myles

714. Economic growth and the role of taxation - Aggregate data (July 2009) Gareth D. Myles

713. Economic growth and the role of taxation - Theory (July 2009) Gareth D. Myles

712. The effectiveness of education and health spending among Brazilian municipalities (July 2009) Luiz de Mello and Mauro Pisu

711. The bank lending channel of monetary transmission in Brazil: A VECM approach (July 2009) Luiz de Mello and Mauro Pisu

710. How does decentralised minimum-wage setting affect unemployment and informality? The case of Indonesia (July 2009) Margherita Comola and Luiz de Mello

709. Intergenerational social mobility in European OECD countries (July 2009) Orsetta Causa, Sophie Dantan and Åsa Johansson

708. Equity in student achievement across OECD countries: an investigation of the role of policies (July 2009) Orsetta Causa and Catherine Chapuis

707. Intergenerational social mobility (July 2009) Orsetta Causa and Åsa Johansson

706. Taxes or grants: what revenue source for sub-central governments? (July 2009) Hansjörg Blöchliger and Oliver Petzold

705. The spending power of sub-central governments: a pilot study (July 2009) Steffen Bach, Hansjörg Blöchliger and Dominik Wallau

704. Price and volume elasticities of Brazilian foreign trade: A profit function approach (July 2009) Luiz de Mello and Mauro Pisu 